\title{
17. LOWER TO MIDDLE EOCENE SEQUENCES OF THE NEW JERSEY COASTAL PLAIN AND THEIR SIGNIFICANCE FOR GLOBAL CLIMATE CHANGE ${ }^{1}$
}

\author{
James V. Browning, ${ }^{2}$ Kenneth G. Miller, ${ }^{2,3}$ Mickey Van Fossen, ${ }^{2}$ Chengjie Liu, ${ }^{2}$ \\ Dorothy K. Pak, ${ }^{3,4}$ Marie-Pierre Aubry, ${ }^{5,6}$ and Laurel M. Bybell ${ }^{7}$
}

\begin{abstract}
Boreholes from Island Beach, Allaire, Atlantic City, and Mays Landing, NJ provide an excellent chronology of lower to middle Eocene passive margin sequences and allow analysis of long-term sea-level changes and sedimentation patterns. These New Jersey sequences are tied directly to the geomagnetic polarity time scale through magnetostratigraphy. Integrated stratigraphy (including magnetostratigraphy, lithostratigraphy, plankton biostratigraphy, and benthic foraminiferal biofacies studies) reveals that these sections contain a relatively continuous record of lowermost Eocene to middle Eocene deposition interrupted by short hiatuses. A sequence boundary at the base of the section spans the Paleocene/Eocene boundary, representing a hiatus from 55.8 to $54.7 \mathrm{Ma}$. A second sequence boundary is associated with a hiatus from 54.0 to $53.4 \mathrm{Ma}$. A third sequence boundary is associated with a hiatus from 52.9 to $52.3 \mathrm{Ma}$. Two major unconformities occur near the lower/middle Eocene boundary at all three boreholes. The first represents a hiatus between 50.9 and $~ 50.5$ to $49.9 \mathrm{Ma}$; the second, between $\sim 49.6$ and $48.6 \mathrm{Ma}$. Early Eocene water depths inferred from benthic foraminiferal biofacies analysis varied from 150 to $200 \mathrm{~m}$ and reached their maximum depth between 53.4 and 53.2 Ma. In the middle Eocene, the sedimentation record is less continuous with hiatuses from 48.3 to $47.9 \mathrm{Ma}, 46.9$ to $44.5 \mathrm{Ma}$, and 43.4 to $41.2 \mathrm{Ma}$. A major lithofacies change from carbonate dominated to siliciclastic dominated occurred by $41.2 \mathrm{Ma}$.

Of the 14 sequences inferred by Exxon for the early to middle Eocene, nine are resolvable on the New Jersey Margin and the remaining five appear to be combined with others. Thus the New Jersey record is consistent with the Exxon record for the early to middle Eocene, although the New Jersey record is better dated. Comparison of the record of sedimentation with the global $\delta^{18} \mathrm{O}$ record shows interesting parallels. It is unlikely that early Eocene sequence boundaries are the result of glacioeustasy because hiatuses from the New Jersey Coastal Plain in this interval do not match increases in the $\delta^{18} \mathrm{O}$ record. In the late middle Eocene, concomitant increases in the planktonic and benthic $\delta^{18} \mathrm{O}$ records coincide with the timing of hiatuses on the New Jersey Coastal Plain. Increases in the $\delta^{18} \mathrm{O}$ records between 43 and 41 Ma coincide with a New Jersey hiatus and a corresponding change in sedimentation type from carbonate dominated to siliciclastic dominated. We conclude that these represent evidence of the first Antarctic ice cap and the beginning of the "Icehouse" world.
\end{abstract}

\section{INTRODUCTION}

Because of debates over the dominant process driving sequence formation, the Eocene provides a critical interval for evaluating causes of global sea-level (eustatic) change and the validity of sequence stratigraphy for global correlation. The only known mechanism for producing the large, rapid sea-level changes that have been reported in the early to middle Eocene is glacioeustasy (Donovan and Jones, 1979; Pitman and Golovchenko, 1983). Minimum benthic foraminiferal $\delta^{18} \mathrm{O}$ values are associated with peak Cenozoic warmth in the early Eocene, an interval believed to lack significant ice sheets (a "Greenhouse World," Miller et al., 1987; 1991). Global climate cooled in at least two steps in the early middle and late middle Eocene (Miller, 1992). The role of ice sheets vs. cooling in these middle to late Eocene $\delta^{18} \mathrm{O}$ increases is debated (e.g., Barron et al., 1991a, 1991b), and this interval has been dubbed the "Doubthouse World" (Miller et al., 1991).

${ }^{1}$ Miller, K.G., and Snyder, S.W. (Eds.), 1997. Proc. ODP, Sci. Results, 150X: College Station, TX (Ocean Drilling Program).

${ }^{2}$ Department of Geological Sciences, Rutgers University, Piscataway, NJ 08855, U.S.A.jvb@rci.rutgers.edu

${ }^{3}$ Lamont-Doherty Earth Observatory of Columbia University, Palisades, NY 10964, U.S.A.

${ }^{4}$ Present address: Department of Geological Sciences, University of California Santa Barbara, Santa Barbara, CA 93106, U.S.A.

${ }^{5}$ Laboratoire de Geologie du Quaternaire, CNRS - Luminy, Marseilles, Cedex 9 16, France.

${ }^{6}$ Woods Hole Oceanographic Institution, Woods Hole, MA 02543, U.S.A.

${ }^{7}$ U.S. Geological Survey, Reston, VA 22092, U.S.A.
These climate changes are reflected in changes in sedimentation on mid-latitude continental shelves. Continental shelf sedimentation throughout much of the Atlantic was dominated by carbonates in the early Eocene (Steckler et al., 1995). Cooling associated with a $\delta^{18} \mathrm{O}$ increase in the earliest Oligocene led to a change in sedimentation type from carbonate dominated to siliciclastic dominated on shelves throughout the mid-latitudes (Steckler et al., 1995; Miller et al., in press). This change from carbonate has been termed the siliciclastic switch (Miller et al., 1996). Our data from the New Jersey Coastal Plain (Fig. 1) suggest that the changeover was not abrupt at the Eocene/Oligocene boundary but rather took place gradually, beginning by the late middle Eocene in onshore boreholes.

Although paleoceanographers generally agree that there were no significant early Eocene ice sheets, Haq et al. (1987) distinguished numerous lower Eocene sequence boundaries and associated sealevel lowerings (Figs. 2, 3). There are four solutions to this apparent paradox:

1. The lower Eocene sequences identified by Haq et al. (1987) were restricted to local basin(s), are not global, and do not reflect eustasy. These lower Eocene sequences are based on few sections (e.g., outcrop studies in northwest Europe, particularly the Isle of Wight; Haq et al., 1987; B.U. Haq, pers. comm., 1994; Berggren and Aubry, 1996) and are among the most poorly documented of the Cenozoic. This solution is probably not valid because there are many other "Greenhouse" intervals for which Haq et al. (1987) show large rapid sea-level changes (e.g., early Cretaceous).

2. The sequences were controlled by low-amplitude sea-level changes (e.g., $10 \mathrm{~m}$ of lowering in $1 \mathrm{~m}$.y. can be explained by 


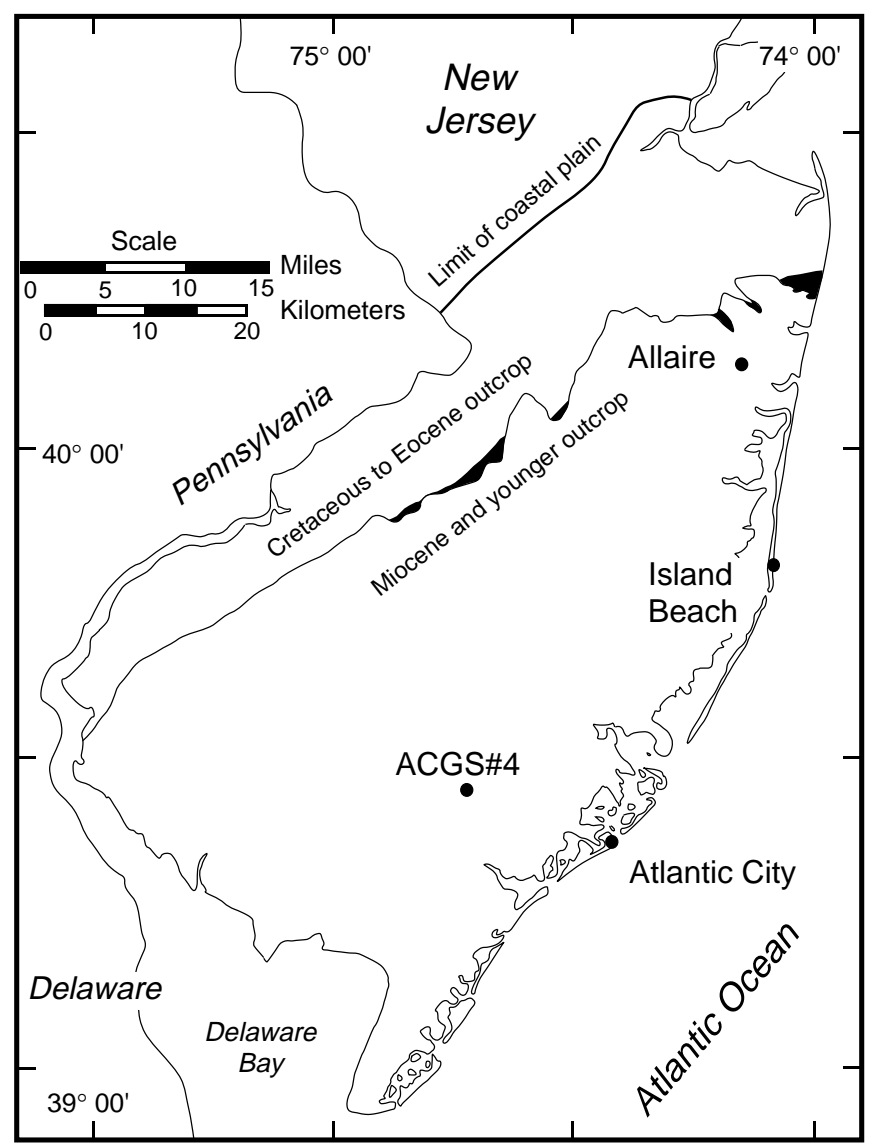

Figure 1. Location map showing boreholes on the New Jersey Coastal Plain discussed in the text. Dark pattern indicates location of Eocene outcrop (after Enright, 1969a). Outcrop belts are shown only for New Jersey.

numerous mechanisms including tectonoeustasy; Donovan and Jones, 1979).

3. Mechanisms of sea-level change are not fully understood.

4. There were large ice sheets throughout much of the Cretaceous to early Eocene.

Evaluating eustatic changes requires precise dating of unconformities (sequence boundaries) on different passive margins (Imbrie et al., 1987). Few studies of Eocene sections have attained direct ties to the geomagnetic polarity time scale (GPTS) and have the high chronostratigraphic resolution (better than 0.5 m.y.) needed to evaluate synchrony of unconformities. This results from a lack of suitable material (e.g., boreholes) for integrated magnetostratigraphic, biostratigraphic, and isotopic stratigraphic studies. Sections in the Gulf Coast (e.g., Hazel et al., 1984; Baum and Vail, 1988; Mancini and Tew, 1991), northwest Europe (Aubry, 1985, 1991; Plint, 1988, Ali and Hailwood, 1995), and New Jersey (e.g., Olsson and Wise, 1987b; Bybell and Self-Trail, 1995) provide the best candidates for integrated studies. Although most Eocene studies have focused on outcrops, boreholes are less subject to weathering than outcrops, stratigraphic positions are more precisely known, fossil preservation is usually better, and more basinal (downdip and more fossiliferous) sections can be analyzed.

New Jersey provides a good record of shallow-water (neritic; $<200 \mathrm{~m}$ ) Eocene deposition, although previous studies of this region were limited by a lack of continuously cored boreholes. New Jersey Eocene outcrops are largely unfossiliferous and poorly dated. Subsurface biostratigraphic studies allowed division of the lower Eocene
(Manasquan Formation) and middle Eocene (Shark River Formation) into seven sequences (Olsson and Wise, 1987a, 1987b), although direct ties to the GPTS were not possible. The first continuously cored borehole on the New Jersey Coastal Plain (the ACGS\#4, [Fig. 1]; Owens et al., 1988) provided material for integrated biostratigraphic (Poore and Bybell, 1988), magnetostratigraphic (Miller et al., 1990), and benthic foraminiferal biofacies (Christensen et al., 1995) studies of the uppermost lower to upper Eocene. Little of the lower Eocene was penetrated (only $40 \mathrm{ft}$ [12.2 m] was recovered). The Paleocene/ Eocene boundary has recently been recovered in an updip borehole drilled at Clayton, New Jersey (Gibson et al., 1993), although the lower to middle Eocene is truncated at this location (only $30 \mathrm{ft}$ [9.1 $\mathrm{m}]$ was recovered).

Drilling at Allaire State Park (Sugarman et al., 1991) and Island Beach, NJ (Miller et al., 1994b; this study) provided the first continuous cores (78 and $226 \mathrm{ft}$ [23.8 and $68.9 \mathrm{~m}$ ]) of the entire lower Eocene section in New Jersey. We analyzed lower and middle Eocene sections at these boreholes and at ACGS\#4 (Owens et al., 1988) and Atlantic City (Miller et al., 1994a) to construct a detailed early to middle Eocene chronology of sea-level change on this passive margin. Integrated stratigraphy, in conjunction with benthic foraminiferal biofacies analysis, is used to identify and date lower to middle Eocene unconformities. The early to middle Eocene sequence chronology developed here (Figs. 2, 3) allows us to evaluate correlations with the inferred sea-level record of Haq et al. (1987) and the $\delta^{18} \mathrm{O}$ record (Kennett and Stott, 1990; Pak and Miller, 1992, 1995).

\section{PREVIOUS WORK}

Conrad (1865) first identified Eocene sediments in New Jersey and gave the name Shark River Marl to small outcrops near Asbury Park, NJ. Cook (1868) subdivided the Eocene, which he termed the upper marl bed, into three units: the Green Marl at the base, the Ash Marl, and the Blue Marl. The Manasquan Formation was formally defined by Clark (1894), who included the Green Marl and the Ash Marl in the Manasquan Formation. The Blue Marl was identified as the Shark River Formation. The first detailed work on Eocene sediments was by Enright (1969a, 1969b). He correlated the Manasquan Formation to the early Eocene and the Shark River Formation to the middle Eocene using the planktonic foraminiferal zones of Bolli (1957a, 1957b). He also divided the Manasquan Formation into two members: the Farmingdale Member, a clayey glauconitic sand, below and the Deal Member, a sandy clay, above. He also divided the Shark River Formation into the Squankum Member, an argillaceous, glauconite sand, and the Toms River Member, a fine to medium quartz sand found only in the subsurface. Ulrich (1976) refined the planktonic foraminiferal biostratigraphy using the Turborotalia cerroazulensis and Globigerinatheka spp. lineages. Charletta (1980) used cluster analysis to distinguish 11 benthic foraminiferal biofacies which he associated with different environments of deposition.

The most definitive micropaleontological study of the New Jersey Coastal Plain Eocene was that of Olsson and Wise (1987a, 1987b), who recognized six early to middle Eocene hiatuses and correlated them to the Haq et al. (1987) curve. They also developed a benthic foraminiferal depth zonation scheme. Unconformities were recognized by abrupt changes in lithology, abrupt changes in benthic foraminiferal biofacies, and gaps in the planktonic foraminiferal and calcareous nannoplankton zones.

The first continuously cored Eocene record was obtained from a borehole drilled near Mays Landing, NJ (the ACGS\#4 borehole; Owens et al., 1988). Owens et al. (1988) described the stratigraphy of the borehole, which recovered a complete middle and upper Eocene section but only $40 \mathrm{ft}(12.2 \mathrm{~m})$ of the lower Eocene Manasquan Formation. They assigned the lower Eocene bioturbated clayey silt to the Manasquan Formation and concluded that it was deposited in middle 


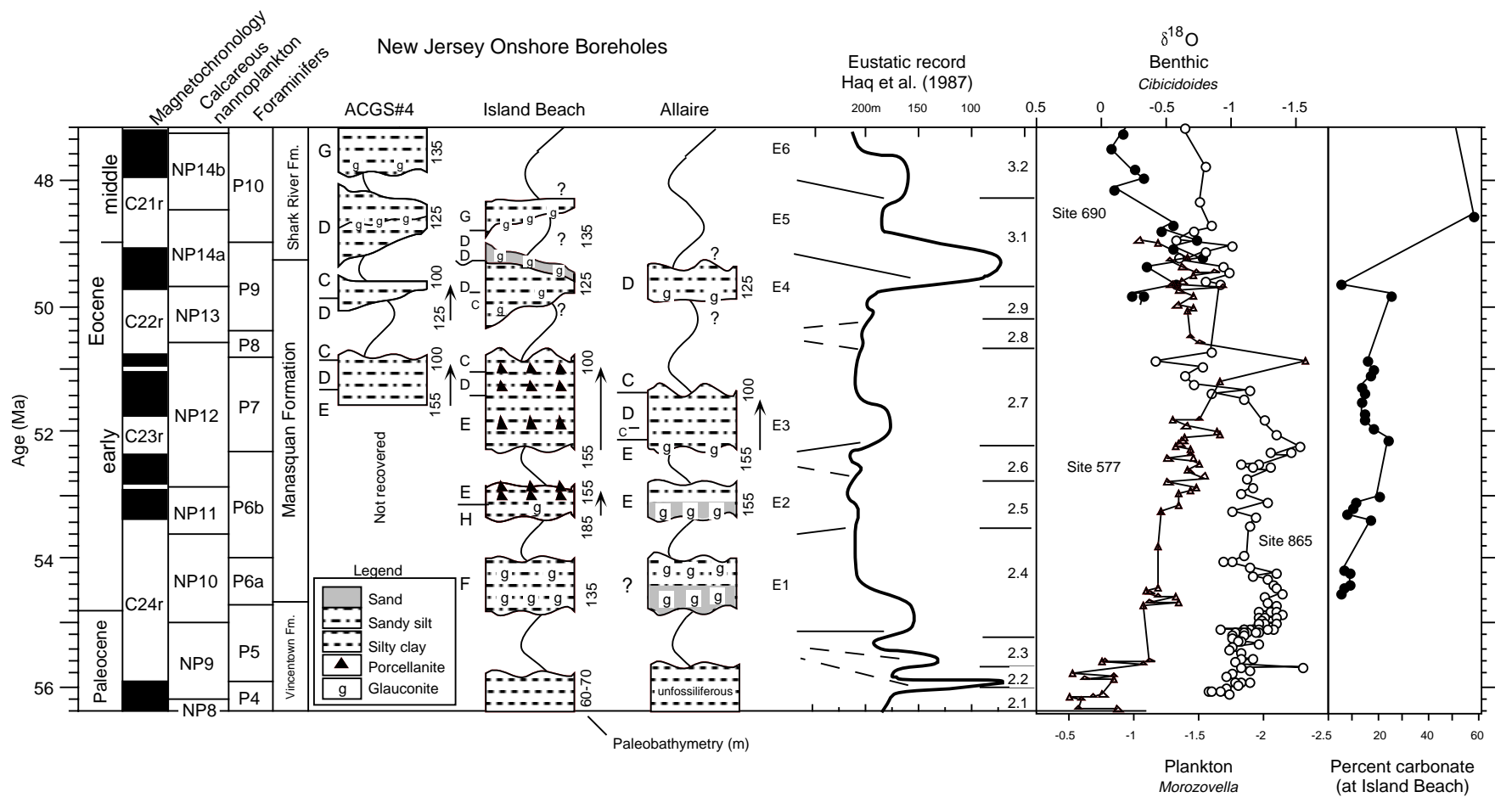

Figure 2. Distribution of sediments from the New Jersey Coastal Plain lower Eocene shown as a function of time and compared to the eustatic record of Haq et al. (1987; recalibrated to the time scale of Berggren et al. [1995]), the benthic foraminiferal $\delta^{18}$ O record from the Southern (Site 690, Kennett and Stott, 1990) and Pacific Oceans (Site 577, Pak and Miller, 1992), and the planktonic foraminiferal $\delta^{18}$ O record from the equatorial Pacific (Site 865, Bralower et al., 1995). Paleodepths are inferred using benthic foraminiferal biofacies (Browning et al., Chapter 16, this volume). The letters $\mathrm{C}-\mathrm{H}$ refer to benthic foraminiferal biofacies. E1-E5 refer to Eocene sequences. Wavy lines indicate unconformities. The time scale of Berggren et al. (1995) is used throughout.

to outer neritic environments. Above the Manasquan is $132 \mathrm{ft}(40.2$ $\mathrm{m})$ of clayey silt and silty, very fine sand assigned to the Shark River Formation. Locally glauconite is very abundant. This formation was also interpreted as a marine shelf deposit. Poore and Bybell (1988) studied the planktonic foraminiferal and calcareous nannoplankton stratigraphy at that borehole. Despite finding all Eocene foraminiferal and nannoplankton zones, they suspected that some unconformities existed. Miller et al. (1990) identified several Eocene to Oligocene unconformities in this borehole using integrated strontium isotopic stratigraphy, magnetostratigraphy, and lithostratigraphy. Aubry (1991) also considered the hiatuses on the New Jersey Coastal Plain. She successfully correlated a hiatus at the lower/middle Eocene boundary in different sedimentary basins around the world but concluded, contrary to what Miller et al. (1990) had found, that there was only one unconformity near the lower/middle Eocene boundary in New Jersey. She relied upon age-depth plots using calcareous nannoplankton data reported by Poore and Bybell (1988). Most recently, Christensen et al. (1995), using benthic foraminifers, reported a number of hiatuses in the ACGS\#4 borehole including two at the lower/ middle Eocene boundary.

\section{METHODS}

We combined studies of lithostratigraphy, planktonic foraminiferal and calcareous nannofossil biostratigraphy (ACGS\#4: Poore and Bybell, 1988; Miller et al., 1990; Island Beach: Miller et al., 1994b; Atlantic City: Miller et al., 1994a; Allaire: this study [Bybell]), magnetostratigraphy (Allaire: this study; Island Beach: Van Fossen, Chapter 22, this volume; ACGS\#4: Miller et al., 1990), and benthic foraminiferal biofacies studies to recognize unconformities and the duration of their associated hiatuses (Figs. 4-6). Disconfor- mities in the three boreholes were identified on the basis of physical and geophysical stratigraphy (including irregular contacts, reworking, bioturbation, major facies changes, and gamma-ray peaks). Paraconformities were inferred from biostratigraphic and magnetochronologic breaks (Fig. 4-6). Studies of benthic foraminiferal biofacies helped confirm and identify disconformities and paraconformities. Recognition of these surfaces allowed identification of sequences. The magnetostratigraphy of the Allaire borehole is presented here for the first time (Fig. 7). The time scale of Berggren et al. (1995) is used throughout. Samples were analyzed at Woods Hole Oceanographic Institution for percent calcium carbonate by weight using the Automated Carbonate System (Ostermann et al., 1990) with a precision of $0.8 \%-1.0 \%$.

Random samples of 300 benthic foraminifers from the greater than $150-\mu \mathrm{m}$ fraction were obtained from $\sim 4$ - to 10-ft intervals (1-3 $\mathrm{m})$. Species were identified using the taxonomy of Bandy (1949) supplemented by Charletta (1980), Jones (1983), and this study. Q-mode factor analysis of percentage data on the entire data set was performed. A visual estimate of species abundances in the 63- to 150$\mu \mathrm{m}$-size fraction was conducted to identify the five paleobathymetric biofacies of Olsson and Wise (1987b). These range from inner-middle neritic (0-65 m; Biofacies 1) to the outer neritic (160-200 m; Biofacies 5).

\section{RESULTS}

\section{Benthic Foraminifers}

Nine stratigraphically interpretable factors explaining $79.8 \%$ of the variation were extracted from the lower to middle Eocene faunas at Island Beach, Allaire, ACGS\#4, and Atlantic City (Figs. 2, 3). These represent eight biofacies that have been used to interpret water 


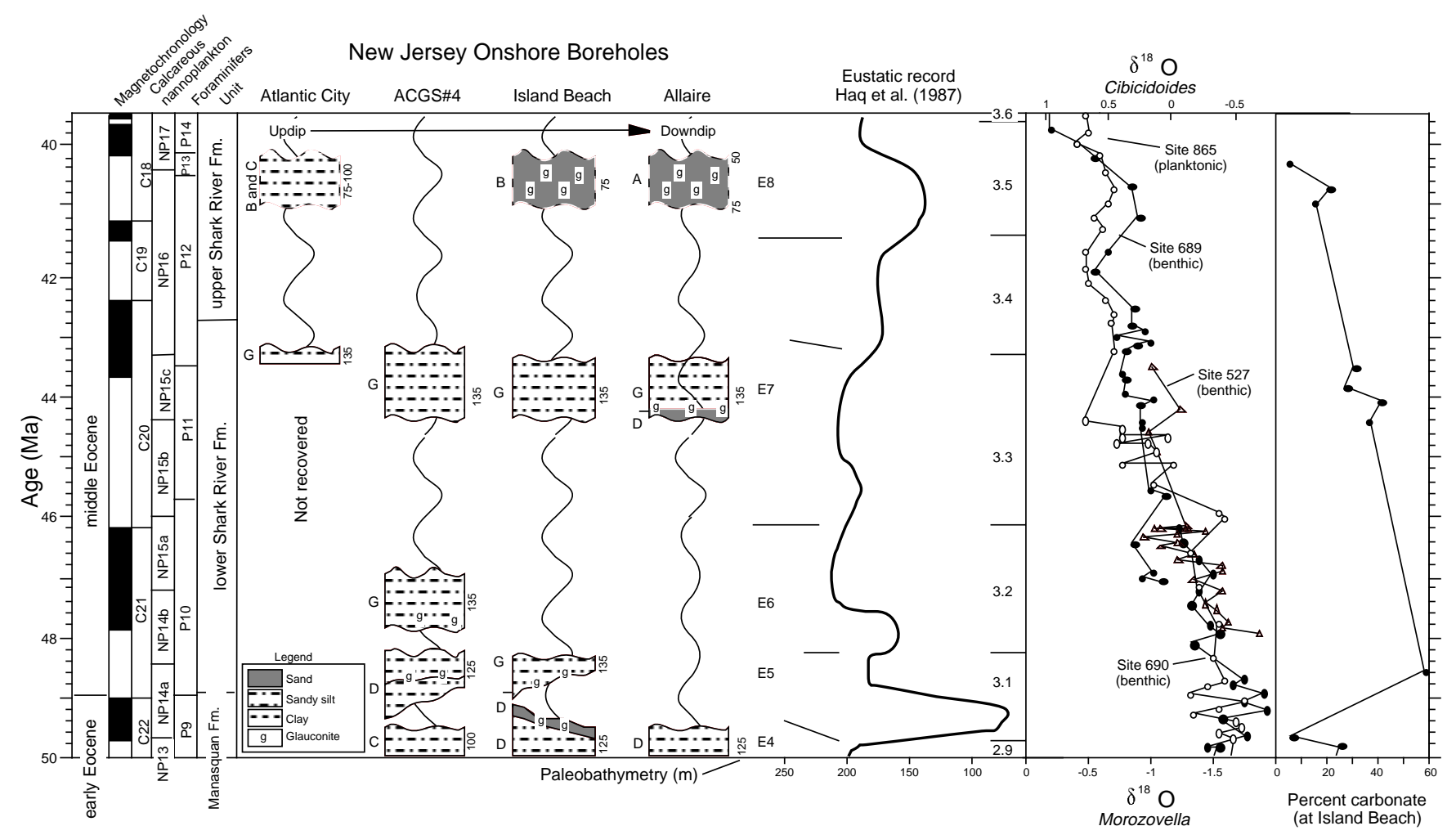

Figure 3. Distribution of sediments from the New Jersey Coastal Plain middle Eocene shown as a function of time and compared to the eustatic record of Haq et al. (1987) (recalibrated to the time scale of Berggren et al. [1995]), the benthic foraminiferal $\delta^{18} \mathrm{O}$ record from the Southern (Sites 689 and 690, Kennett and Stott, 1990) and South Atlantic Oceans (Site 527, Shackleton et al., 1984), and the planktonic foraminiferal record from the equatorial Pacific (Site 865, Bralower et al., 1995). Paleodepths are inferred using benthic foraminiferal biofacies (Browning et al., Chapter 16, this volume). E4-E8 refers to Eocene sequences. All other capital letters refer to benthic foraminiferal biofacies. Wavy lines indicate unconformities. The time scale of Berggren et al. (1995) is used throughout.

depths on the continental shelf (detailed descriptions of the biofacies and derivation of the paleodepths is given in Browning et al., Chapter 16 , this volume). The biofacies and the factors that define them are discussed from shallowest (Biofacies A) to deepest (Biofacies H):

Biofacies A is defined by Factor 5 (4.8\% explained; 190-175 ft [57.9-53.3 m] at Allaire; 41.2-40.2 Ma) and is characterized by Globobulimina ovata, Cibicidina praeconcentricus, Gyroidinoides octocameratus, and Alabamina wilcoxensis.

Biofacies B is defined by Factor 7 (4.4\% explained; $1420-1390 \mathrm{ft}$ [432.8-423.7 m] at Atlantic City; 800-780 ft [243.8-237.7 m] at Island Beach; 205-200 ft [62.5-61.0 m] at Allaire; 41.2-40.5 Ma) and is characterized by Cibicidoides pippeni and Hanzawaia blanpiedi.

Biofacies $\mathrm{C}$ is defined by Factor 6 (5.5\% explained) and is characterized by Cibicidoides cf. pseudoungerianus, Anomalinoides acuta, and Cibicidoides cocoaensis.

Biofacies D is defined by Factor 1 (20.3\% explained) and is characterized by Siphonina claibornensis. Biofacies C and D alternate in dominance between 914 and $855 \mathrm{ft}(278.6$ and $260.6 \mathrm{~m})$ at Island Beach, 270 and $230 \mathrm{ft}(82.3$ and $70.1 \mathrm{~m})$ at Allaire, and 938 and 893 $\mathrm{ft}$ (285.9 and 272.2 $\mathrm{m}$ ) at ACGS\#4 (51.4-49.6 Ma).

Biofacies E is defined by Factor 3 (15.3\% explained; $1000-914 \mathrm{ft}$ [304.8-278.6 m] at Island Beach, 299-270 ft [91.1-82.3 m] at Allaire, 945-938 ft [288.0-285.9 m] at ACGS\#4; 53.2-51.4 Ma) and is characterized by Cibicidoides aff. subspiratus.

Biofacies $\mathrm{F}$ is defined by Factor 4 (7.5\% explained) and is characterized by high positive scores for Cibicidoides cf. mimulus, Osangularia expansa, and Anomalinoides acuta. It dominates at Island Beach at the base of the Manasquan Formation (1075.5-1015 ft [327.8-309.4 m]; 54.7-54.0 Ma; earliest Eocene).
Biofacies $\mathrm{G}$ is defined by Factors 2 and 9. Factor 2 (16.1\% explained; $852-800 \mathrm{ft}[259.7-243.8 \mathrm{~m}]$ at Island Beach; $224-210 \mathrm{ft}$ [68.3-64 m] at Allaire; 848, 830-793 ft [258.5, 253.0-241.7 m] at ACGS\#4; $1450-1430 \mathrm{ft}$ [442.0-435.9 m] at Atlantic City; 44.5-43.4 $\mathrm{Ma})$ is characterized by Cibicidoides subspiratus. Factor $9(2.9 \%$ explained; 870-852 and $843 \mathrm{ft}$ [265.2-260 and 256.9 m] at ACGS\#4; 47.9-47 Ma) is characterized by Cibicidoides cf. praemundulus.

Biofacies $\mathrm{H}$ is defined by Factor 8 (3.0\% explained; $1015-1000 \mathrm{ft}$ [309.4-304.8 m] at Island Beach; 53.4-53.2 Ma) and is characterized by Cibicidoides eocaena, Eponides jacksonensis, and Gavelinella capitatus,

These biofacies have predictive value concerning the depositional environments of the sediments in which they occur (Browning et al., Chapter 16, this volume). By integrating a paleoslope modeling technique (Olsson and Wise, 1987b) with studies of modern benthic foraminiferal faunal distributions, lithofacies analysis, and comparison with the biofacies of Olsson and Wise (1987b), changes in faunas were related to changes in paleowater depth (see Browning et al. [Chapter 16 , this volume] for derivation of the paleodepths for these biofacies). This technique allowed interpretation of the absolute paleodepths these faunas inhabited. The deepest water fauna is Biofacies $\mathrm{H}$ with a paleodepth or $185 \pm 15 \mathrm{~m}$. Biofacies $\mathrm{E}$ has a paleodepth of $155 \pm 15$ $\mathrm{m}$; Biofacies D has a paleodepth of $125 \pm 15 \mathrm{~m}$; Biofacies F and G have paleodepths of $135 \pm 25 \mathrm{~m}$; Biofacies $\mathrm{C}$ has a paleodepth of 100 $\pm 10 \mathrm{~m}$; Biofacies B has a paleodepth of $75 \pm 15 \mathrm{~m}$; and Biofacies A, the shallowest water fauna, has a paleodepth of less than $65 \mathrm{~m}$ and probably $50 \pm 15 \mathrm{~m}$. Maximum paleodepths of 170-200 m (Biofacies $\mathrm{H})$ were attained during the early Eocene ( 53.4-53.2 Ma; $1019-1000$ $\mathrm{ft}$ [310.6-304.8 $\mathrm{m}$ ] at Island Beach). The remainder of the early 


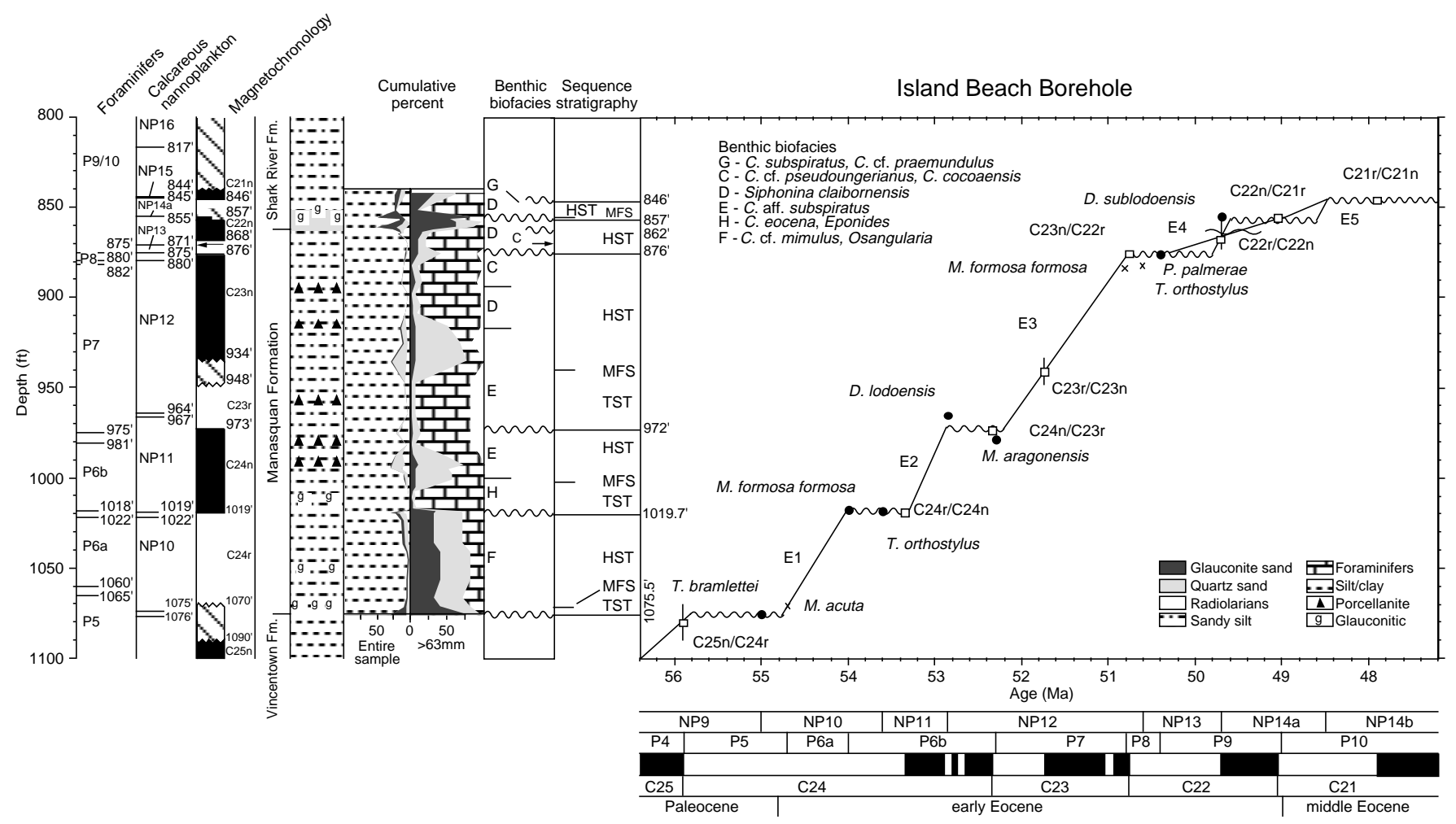

Figure 4. Age vs. depth plot for significant biostratigraphic and magnetic events from the Island Beach borehole lower Eocene. $\mathrm{X}=$ faunal highest occurrences, solid circles $=$ faunal lowest occurrences, and open squares $=$ magnetic reversals.

Eocene and most of the middle Eocene sections were deposited at inferred paleodepths of 90-170 m (Biofacies C, D, E, F, and G).

\section{Integrated Stratigraphy}

Age-depth diagrams of the Island Beach and ACGS\#4 boreholes (Figs. 4-6) integrate ages of significant bioevents and magnetostratigraphy. The two boreholes have comparable magnetobiostratigraphic resolution (Fig. 8), although the lower part of the lower Eocene was not cored at ACGS\#4. The Atlantic City borehole recovered little of the middle Eocene (Fig. 3). The updip Allaire core (Fig. 7 ) is more difficult to date accurately, because the section is more condensed, magnetostratigraphy is difficult in the sandier sediments, and biostratigraphic markers are rarer. Correlation to Island Beach was accomplished using available biostratigraphy, magnetostratigraphy, and benthic biofacies (Fig. 8). Depth-depth diagrams among the three boreholes were used to delineate sequences (Fig. 8). An attempt was also made to tie the facies to specific systems tracts to gain a clearer understanding of deposition and to attempt to date the maximum flooding surfaces (MFS) within each sequence. In the New Jersey Coastal Plain, lowstand systems tracts are absent, and it is only the transgressive and highstand systems tracts that occur. A typical New Jersey sequence has a glauconite sand at the base, interpreted to be the transgressive systems tract (TST), overlain by early highstand systems tract (HST) clays and silts with late HST sands at the top (Sugarman et al., 1993). New Jersey Eocene onshore sediments do not always resemble a typical New Jersey sequence, because they rarely have sand at the base. Eocene sequences are from relatively deep water, and the basal sediments occur as a condensed section. The MFS is associated with this condensed interval (Posamentier et al., 1988). Condensed intervals can be recognized by a higher diversity of planktonic foraminifers than intervals above or below (Powell, 1992). In addition, glauconite tends to accumulate at those times because siliciclastic sediments are trapped in the near shore region.

\section{Sequence E1}

A disconformity at $1075.5 \mathrm{ft}$ (327.8 m) at Island Beach (Fig. 4), separating the Vincentown and Manasquan Formations, is indicated by an irregular surface evidencing erosion, a lithofacies shift, and a sharp gamma log increase. The extent of the hiatus is disputed, as is the position of the Paleocene/Eocene boundary. The surface underlying the unconformity is not easily dated. Sediments below it are normally magnetized, and those above are reversed representing the disconformable transition from Chronozone C25n to C24r. The transition from Chronozone C25n to C24r is no younger than 55.9 Ma. The age of the surface above is controversial. M.-P. Aubry (pers. comm., 1995) found that the first occurrence (FO) of Tribrachiatus bramlette $i$, and hence the NP9/NP10 boundary, is coincident with the Vincentown/Manasquan boundary at Island Beach, and Tribrachiatus contortus morphotype A is also found at the base of the Manasquan Formation. Berggren et al. (1995) found that the range of the latter species is from 54.37 to $54.17 \mathrm{Ma}$, making the base of the Manasquan Formation no older than 54.37 Ma. Hence, according to Aubry's interpretation, the Paleocene/Eocene boundary is lost in the contact, and the hiatus is $\sim 1.53 \mathrm{~m}$.y. (from 55.9 to $54.37 \mathrm{Ma}$ ).

Pak (1995) examined stable isotopes of oxygen and carbon and found excellent correlation between the signals found at Island Beach and in deep-sea cores. In particular, she found that a large decrease in the $\delta^{13} \mathrm{C}$ record at Island Beach resembles a similar shift in the latest Paleocene $\delta^{13} \mathrm{C}$ record of deep-sea boreholes (the Carbon Isotope Excursion, CIE), leading her to conclude that the Paleocene/Eocene (P/E) boundary is preserved in the Island Beach borehole at $\sim 1073 \mathrm{ft}$ (327 m). Pak's (1995) interpretation requires a short hiatus $(\sim 0.6$ m.y.) associated with the disconformity at $1075.5 \mathrm{ft}(327.8 \mathrm{~m})$.

A slight variation on this hypothesis is that a sequence boundary lies in the interval between 1045 and $1055 \mathrm{ft}$ (318.5 and $321.6 \mathrm{~m}$ ), which was lost during drilling. This would allow the base of the Manasquan to be Paleocene and the carbon isotope increase of Pak (1995) to be the 


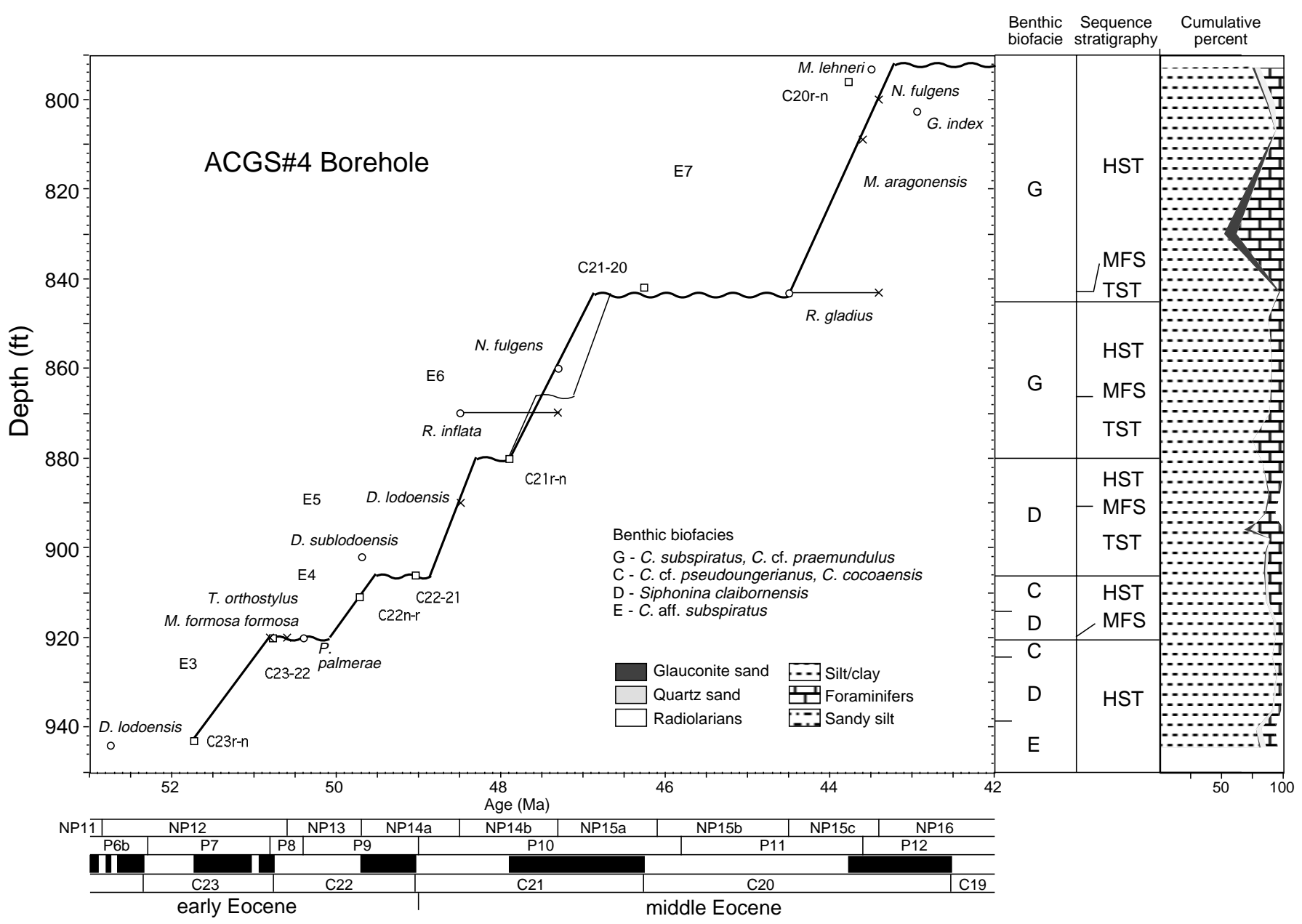

Figure 5. Age vs. depth plot for significant biostratigraphic and magnetic events from the ACGS\#4 borehole. $X=$ faunal highest occurrences, open circles $=$ faunal lowest occurrences, and open squares $=$ magnetic reversals.

CIE. The lower sequence would have ages of 55.6-55.3 Ma, whereas the upper sequence would be between 54.3 and $54.0 \mathrm{Ma}$.

Stensoina beccariformis was found in all samples between the Manasquan/Vincentown Formation boundary to $1055 \mathrm{ft}$ (321.6 m). In the deep sea, this taxon becomes extinct at the CIE (van Morkhoven et al., 1986). There are three possibilities: first, that the range of this taxon is incompletely known; second, the specimens are reworked from older sediments; or third, that the sediments are Paleocene.

The planktonic foraminifers do not give a definitive answer. A single specimen of Morozovella acuta was found at $1074 \mathrm{ft}(327.4$ $\mathrm{m}$ ), along with a single specimen of Pseudohastigerina sp. Berggren et al. (1995) report that the highest occurrence of $M$. acuta coincides with the highest occurrence of $M$. velascoensis in deep-sea boreholes, indicating a Paleocene age. However, Berggren et al. (1995) state that whereas Pseudohastigerina has a FO at the P/E boundary in the tropics, its FO is progressively younger in higher latitude cores. Pseudohastigerina is found continuously throughout the Manasquan Formation at the Island Beach borehole. The interpretation adopted for this paper is that the highest occurrence of $M$. acuta is accurate, and the base of the Manasquan Formation is $54.7 \mathrm{Ma}$ with a hiatus of 1.2 m.y. (from 55.9 to $54.7 \mathrm{Ma}$ ). This would require either an extension of the range of $T$. contortus morphotype A or require some contamination, but is consistent with the base of the Manasquan Formation being NP10 (Aubry, pers. comm., 1995). The alternative, that deposition took place between 54.37 and 54.17 Ma based on the range of $T$. contortus morphotype A of Berggren et al. (1995), re- quires that the sequence above the unconformity have an anomalously high sedimentation rate $(85 \mathrm{~m} / \mathrm{m}$.y.).

The lowermost Eocene sequence continues to $1019.7 \mathrm{ft}$ (310.8 m) where there is a subtle break in sedimentation. This sequence is dominated by Biofacies F, which is characterized by Cibicidoides cf. mimulus and Osangularia expansa. Also important in this assemblage are Anomalinoides acuta, and Bulimina macilenta. Cibicidoides spp. dominates at the top of the sequence. The sequence consists of silty clay with glauconite sand at the base $(1075.5-1071.6 \mathrm{ft}$ [327.8-326.6 m]), laminated clay-glauconite clay $(1071.6-1071.2 \mathrm{ft}$ [326.6-326.5 m]), capped with slightly sandy silts $(1071.2-1019.7 \mathrm{ft}$ [326.5-310.8 m]) that contain equal parts of quartz and glauconite. The change in lithology, at $1071.6 \mathrm{ft}(326.6 \mathrm{~m})$, is probably associated with a change in systems tracts from a TST to a HST and may be a MFS. This horizon is also associated with the only occurrence in the sequence of $M$. acuta, which may indicate deeper water on the shelf that allowed this taxon to penetrate. The inferred age of this surface is dependent upon the age model chosen. Assuming one sequence in the interval, the MFS is dated at $\sim 54.4 \mathrm{Ma}$. This sequence represents predominantly HST deposition with a highly reduced TST. There is little change in the benthic biofacies across this surface and few changes in the biofacies in this entire sequence, indicating that waterdepth changes in this interval were probably less than $30 \mathrm{~m}$. The entire sequence was deposited in $0.7 \mathrm{~m}$.y. with a sedimentation rate of $24 \mathrm{~m} / \mathrm{m}$.y. Biofacies F indicates paleodepths of $135 \pm 25 \mathrm{~m}$. Average percent carbonate for these sediments is $\sim 7 \%$. 


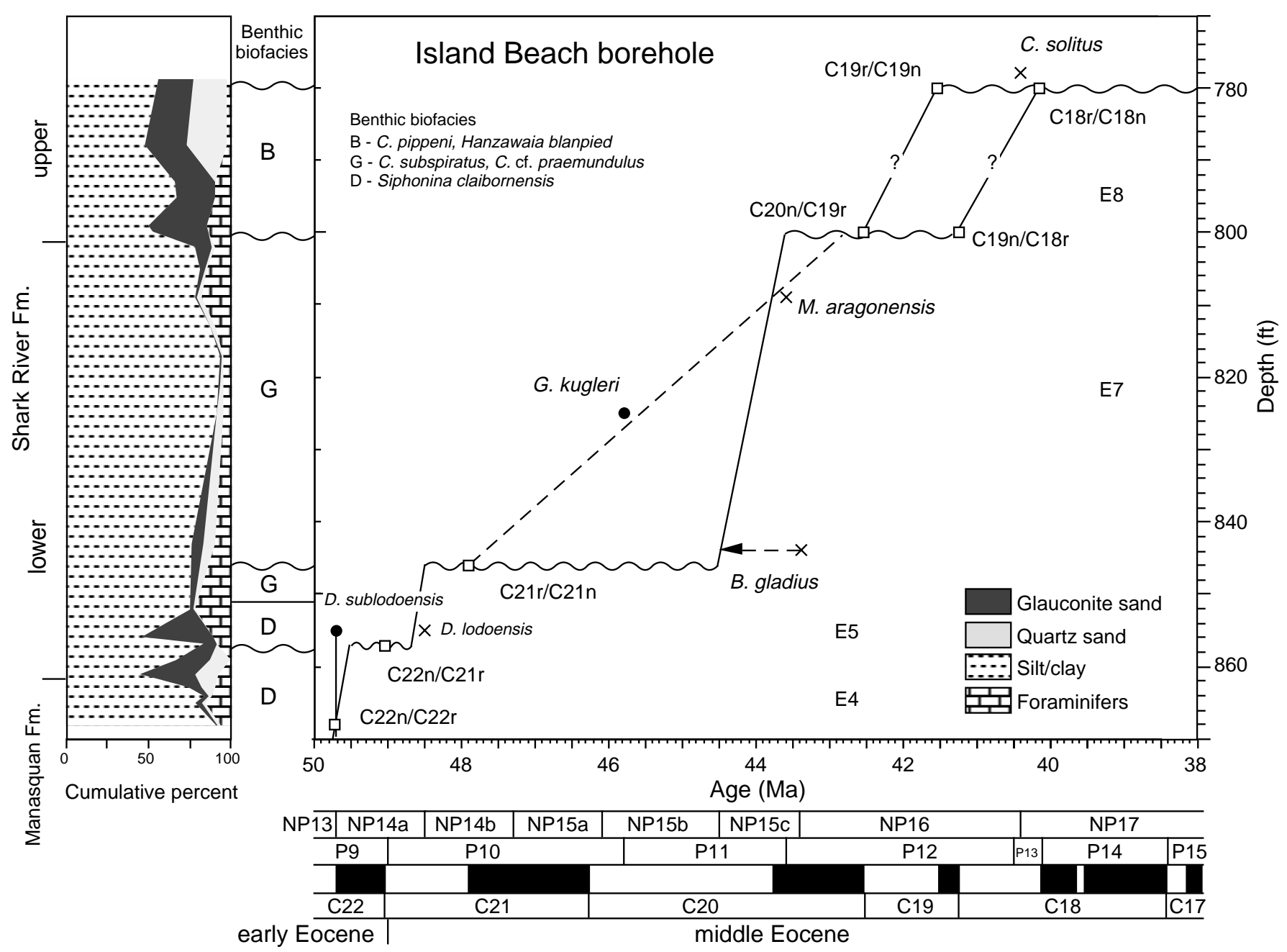

Figure 6. Age vs. depth plot for significant biostratigraphic and magnetic events from the Island Beach borehole middle Eocene. $\mathrm{X}=$ faunal highest occurrences, solid circles $=$ faunal lowest occurrences, and open squares $=$ magnetic reversals.

\section{Sequence E2}

An unconformity, separating glauconitic sandy silts below from silts above, occurs at $1019.7 \mathrm{ft}$ (310.8 m) at Island Beach (Fig. 4). The unconformity is marked by a thin clay layer with an increase in glauconite immediately above the surface. A short hiatus of $0.6 \mathrm{~m}$.y. (from 54.0 to $53.4 \mathrm{Ma}$ ) is associated with this surface. The surface marks the change from Chronozone C24r to C24n (53.4 Ma). Morozovella formosa formosa $(\mathrm{FO}=54.0 \mathrm{Ma})$ and Tribrachiatus orthostylus $(53.6$ Ma) have lowest occurrences in the sediments above this surface (Fig. 4). Minor amounts of biofacies mixing occur across the surface (i.e., the sample at $1019.0 \mathrm{ft}[310.6 \mathrm{~m}]$ is a mixture of Biofacies $\mathrm{F}$ and $\mathrm{H}$ ), although there is a clear deepening across the surface from paleodepths of 135-185 m (Biofacies F to H, Fig. 2). We interpret this deepening as reflecting a change from the regressive HST (Posamentier et al., 1988) of the underlying sequence to the deepest water "condensed section" of the overlying sequence (Loutit et al., 1988).

The E2 sequence at Island Beach, between 1019.7 and $972 \mathrm{ft}$ ( 310.8 and $296.3 \mathrm{~m}$ ) is fine grained. It was deposited between 53.4 and 52.9 Ma (late Biochron NP11 and earliest NP12). The base contains glauconite sand similar to the New Jersey sequences described from Miocene sections (Sugarman et al., 1993). The sediments between 1018 and $1000 \mathrm{ft}$ (310.3 and $304.8 \mathrm{~m}$ ) are almost entirely silty clay with very little sand, and the sand fraction is dominated by foraminifers. The sediments above this become increasingly sand rich, up to $25 \%$, with the sand fraction dominated by fine and very fine quartz. At $990 \mathrm{ft}(301.8 \mathrm{~m})$, radiolarians become important in the sand fraction and constitute $20 \%$ of sands to the top of the sequence. These siliceous microfossils have been diagenetically altered, in places, to porcellanites. Especially thick $(>15 \mathrm{~cm})$ porcellanites are found at 992.7-993.2 ft (302.6-302.7 m) and 976.6-977.2 ft (297.7-297.9 $\mathrm{m})$. The sedimentation rate for this sequence is $29 \mathrm{~m} / \mathrm{m}$.y. The percent carbonate is $\sim 10 \%$.

The base of Sequence E2 (1019.7-1000 ft [310.8-304.8 m]) consists of Biofacies H, which is dominated by Cibicidoides eocaena, Eponides jacksonensis, and Gavelinella capitatus. Species common higher in the section such as Cibicidoides cocoaensis, Cibicidoides pseudoungerianus, and Cibicidoides vicksburgensis are absent. At $1000 \mathrm{ft}(304.8 \mathrm{~m})$, benthic Biofacies H is replaced by Biofacies E. Biofacies E dominates most of the Manasquan Formation and is characterized by the common occurrence of Cibicidoides aff. subspiratus, which dominates the biofacies, and Anomalinoides acuta, Cibicidoides eocaena, and Turrilina robertsi. Biofacies $\mathrm{H}$ was deposited in paleowater depths of $\sim 185 \pm 15 \mathrm{~m}$, representing the deepest water of the Cenozoic, and Biofacies $\mathrm{E}$ was deposited in paleowater depths of $\sim 155 \pm 15 \mathrm{~m}$. 


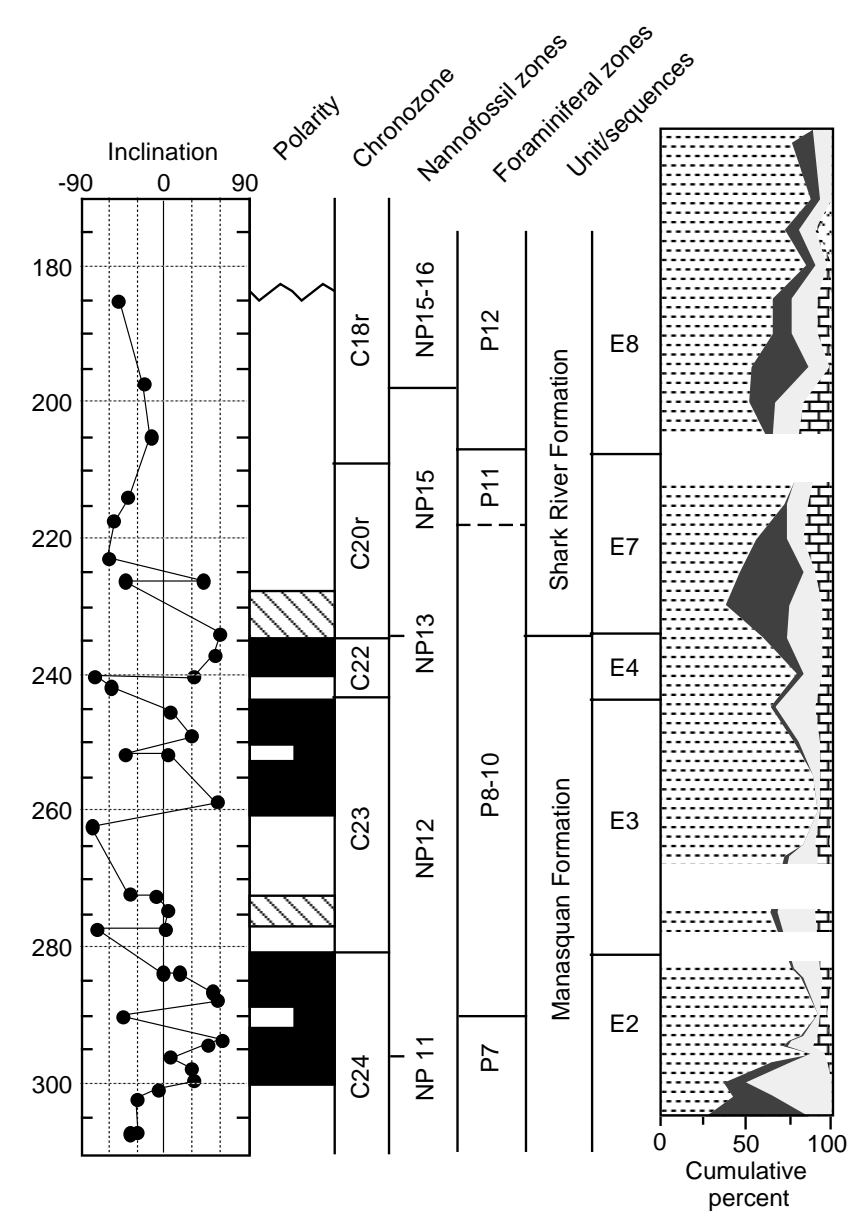

Figure 7. Magnetostratigraphic and biostratigraphic data for the Allaire borehole. See Figure 6 for explanation of lithologic symbols.

Sequence E2 is also present at the Allaire State Park borehole. It is $\sim 20 \mathrm{ft}$ thick $(6.1 \mathrm{~m})$ and consists of coarse glauconite sand at the base that rapidly fines upward to a slightly sandy clay. The biofacies are similar to those at Island Beach with dominant Cibicidoides $\mathrm{cf}$. subspiratus (Biofacies E). The uppermost sample in this sequence contains an abundance of Turrilina robertsi, which is an indicator of Olsson and Wise's (1987b) Biofacies 4 and 3. This may indicate that some shallowing took place during deposition, although a coeval shallowing is not apparent at Island Beach. We interpret the change from Biofacies $\mathrm{H}$ to Biofacies $\mathrm{E}$ and the shift in lithology from clay to slightly sandy clay to be the MFS and the shift from transgressive facies to highstand facies. This change is dated as 53.1 Ma at Island Beach.

\section{Sequence E3}

A distinct surface at $972 \mathrm{ft}(296.3 \mathrm{~m})$ at Island Beach is marked by a porcellanite in the underlying material and an erosional surface. Discoaster lodoensis has its lowest occurrence above this surface, and Morozovella aragonensis occurs $3 \mathrm{ft}(0.9 \mathrm{~m})$ below the surface, indicating a hiatus from 52.9 to $52.3 \mathrm{Ma}$. The occurrence of $M$. aragonensis below the surface is attributed to contamination or downward piping. This surface also represents the contact of Chronozones $\mathrm{C} 24 \mathrm{n}$ and $\mathrm{C} 23 \mathrm{r}$.

Sequence E3 extends to $876 \mathrm{ft}$ (267 m) at Island Beach (upper two-thirds of calcareous nannoplankton Zone NP12; planktonic foraminiferal Zone P7; Magnetochron C23). This sequence does not have a basal glauconite and thus is not a typical New Jersey sequence. It is dominated by silt and clay with sand rarely exceeding $20 \%$ of the sediments. The sand fraction between 972 and $940 \mathrm{ft}$ (296.6 and $286.5 \mathrm{~m}$ ) is dominated by foraminiferal and radiolarian tests. Between 940 and $915 \mathrm{ft}(286.5$ and $278.9 \mathrm{~m})$, the sand fraction is dominated by fine and very fine quartz sand. From 915 to $876 \mathrm{ft}$ (278.9$267 \mathrm{~m}$ ), the sand fraction is dominated by foraminiferal tests with glauconite, quartz, and radiolarian tests being relatively unimportant. Glauconite is rare to absent in these sediments. The percent carbonate in these sediments averages $15 \%$. The foraminifers at the base of this sequence are characterized by Biofacies $\mathrm{E}$. Biofacies $\mathrm{E}$ is replaced at $914 \mathrm{ft}(278.6 \mathrm{~m})$ by Biofacies D, which is characterized by Siphonina claibornensis along with Anomalinoides acuta. This is replaced at $896 \mathrm{ft}(273.1 \mathrm{~m})$ by Biofacies C, which is characterized by Cibicidoides pseudoungerianus, Cibicidoides cocoaensis, and Anomalinoides acuta. This paleodepths of this sequence shallowed from 155 $\pm 15 \mathrm{~m}$ at the base to $100 \pm 10 \mathrm{~m}$ at the top.

Sequence E3 is also found in the Allaire State Park borehole (280-243 ft [85.3-74.1 m]). As at Island Beach, benthic foraminiferal Biofacies $E$ at the base is replaced by Biofacies D $(265 \mathrm{ft}[80.8 \mathrm{~m}])$, which is in turn replaced by Biofacies C (248 ft [75.6 m]). At Allaire, the sediments are slightly more glauconitic at the base at $275 \mathrm{ft}(83.8$ $\mathrm{m})$. They become more clay rich; at the top fine to very fine sand becomes more dominant.

Sequence E3 is the oldest sequence recovered at the ACGS\#4 borehole. It is fine grained, and the sand-sized fraction consists of $\sim 20 \%$ fine to very fine quartz and $25 \%$ diatom tests. The remainder is foraminiferal tests. The change in foraminiferal biofacies from Biofacies $\mathrm{E}$ at the base to Biofacies $\mathrm{C}$ at the top clearly shows that shallowing occurs within this sequence.

At Island Beach, this sequence contains a number of thick (up to $0.3 \mathrm{~m}$ ) porcellanite units correlative to Reflector $\mathrm{A}^{\mathrm{c}}$ (Tucholke and Mountain, 1979; Fig. 2). Species richness, equitability, and percent planktonic foraminifers decrease throughout the interval from high values at the base, which is indicative of shallowing sea level (Gibson and Buzas, 1973).

The MFS is difficult to interpret in this sequence. As in sequence $\mathrm{E} 2$, the MFS is interpreted to be at the point where the sand fraction increases significantly. This takes place at $940 \mathrm{ft}(286.5 \mathrm{~m})$ at Island Beach (51.8 Ma). Because of poor recovery, the MFS cannot be interpreted at Allaire. The base of this sequence, and hence the MFS, was not recovered at ACGS\#4.

\section{Sequence E4}

We infer an unconformity, dated at $50.9 \mathrm{Ma}$, at all three boreholes $(876 \mathrm{ft}[267 \mathrm{~m}]$ at Island Beach, $243 \mathrm{ft}[74.1 \mathrm{~m}]$ at Allaire, and $920 \mathrm{ft}$ [280.4 $\mathrm{m}]$ at ACGS\#4). This is a paraconformity at Island Beach with no physical surface observed in the core. This unconformity is inferred from a deepening associated with a biofacies shift from Biofacies $\mathrm{C}$ to Biofacies $\mathrm{D}$ above. It coincides with the contact between Chronozone C23n and a truncated upper C22r; it is just above the highest occurrences of Morozovella formosa formosa and Tribrachiatus orthostylus (Fig. 4). The lowest occurrence of Planorotalites palmerae is slightly above the unconformity at $875 \mathrm{ft}(266.7 \mathrm{~m})$ at Island Beach, indicating that planktonic foraminiferal Zone P8 is highly truncated or missing and that the unconformity encompasses much of early Chron C22r. At the ACGS\#4 borehole, the absence of Zone $\mathrm{P} 8$ is indicated by the co-occurrence of Planorotalites palmerae and Morozovella formosa formosa at $920.5 \mathrm{ft}$ (280.6 m; Fig. 5). The hiatus associated with this unconformity is at least 0.4 m.y. (50.9$50.5 \mathrm{Ma}$ ), if a sedimentation rate of $5 \mathrm{~m} / \mathrm{m}$.y. is inferred for the sediments above the unconformity, or 1.0 m.y. (50.9-49.9 Ma) if a sedimentation rate of $20 \mathrm{~m} / \mathrm{m} . \mathrm{y}$. is inferred (Figs. 2, 4). The lack of a physical surface with a hiatus of this magnitude is unusual in the New Jersey Coastal Plain. 


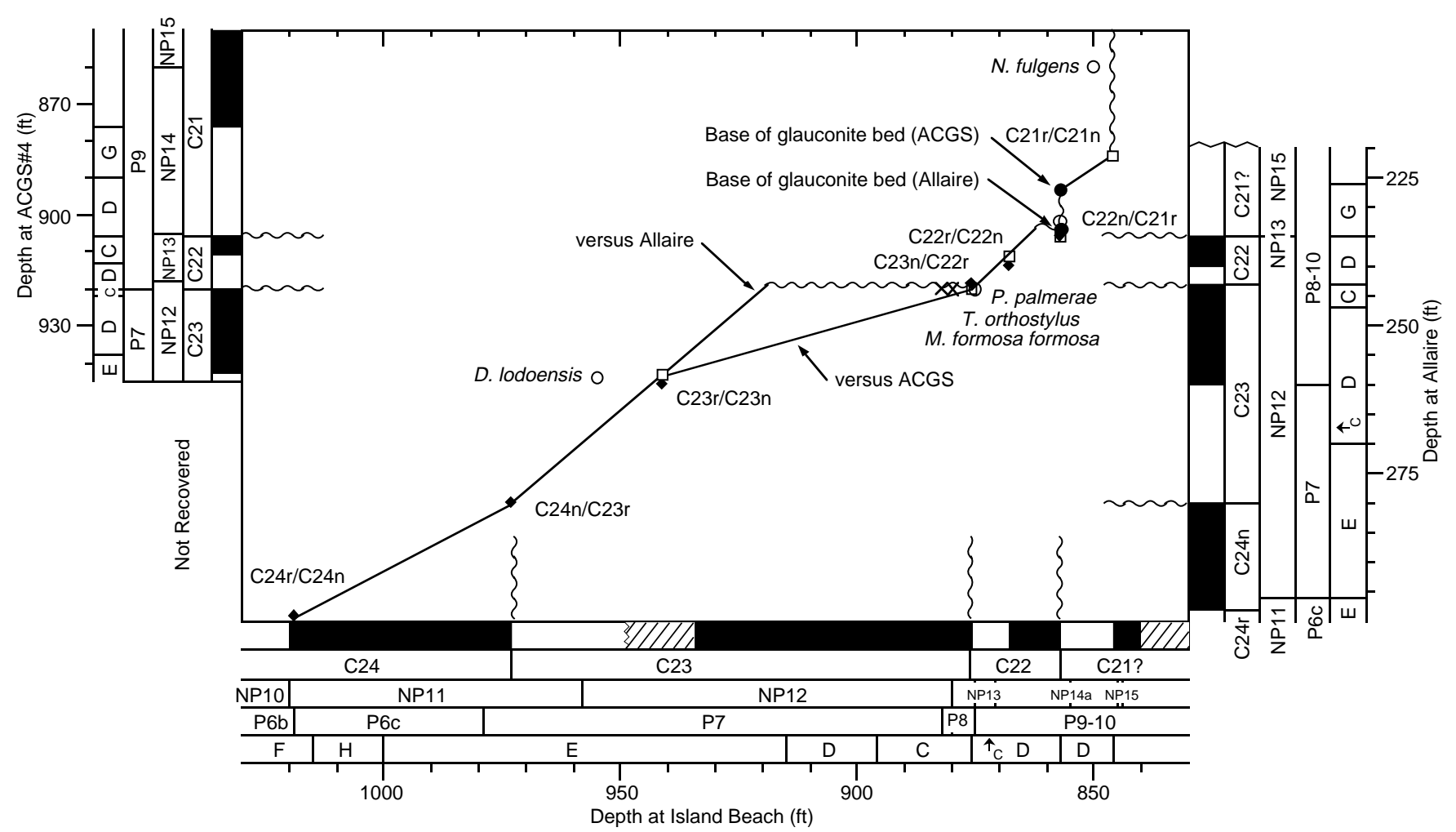

Figure 8. Comparison of the boreholes as a function of depth below surface using age significant bioevents and magnetic reversals to correlate the cores. Wavy lines indicate unconformities. Solid squares = magnetic reversals at Allaire, open squares $=$ magnetic reversals at ACGS\#4, open circles $=$ faunal lowest occurrences, and $\mathrm{X}=$ faunal highest occurrences.

The sediments deposited between 50.5 and $49.5 \mathrm{Ma}$ at all three sites are intensely bioturbated with dark gray clays interbedded with pale yellow clays. A sharp surface at $862 \mathrm{ft}(262.7 \mathrm{~m})$ at Island Beach is associated with a "kick" in the gamma-ray log and a change from a pale yellow marl below to a glauconitic silty sand above; however, there is no discernible hiatus associated with this surface that is confined to Chronozone C22n. The unit between 862 and $857 \mathrm{ft}(262.7$ and $261.2 \mathrm{~m}$ ) at Island Beach grades upward into an pale yellow marl that apparently is not present at ACGS\#4 (Fig. 8). Very coarse glauconite and quartz sand occurs at $862 \mathrm{ft}(262.7 \mathrm{~m})$. The percent carbonate is $5 \%$ above $862 \mathrm{ft}(262.7 \mathrm{~m})$ and $25 \%$ in the sediments below. This surface separates the Manasquan and Shark River Formations. These sediments are dominated by Biofacies D, indicating paleodepths of $135 \pm 15 \mathrm{~m}$.

The absence of a glauconite layer at the base makes it difficult to resolve the MFS in the sequence. The fact that these sediments are highly bioturbated may mask these thin facies variations. The juxtaposition of $M$. formosa formosa and P. palmerae in the ACGS\#4 borehole may indicate a highly condensed section and that the MFS is at the base of the sequence.

\section{Sequence E5}

Another major unconformity occurs at all three boreholes within a stratigraphic interval correlative to the top of Chronozone C22n. At Island Beach, this surface $(857 \mathrm{ft}$ [261.2 m]) is represented by a sharp facies change from pale yellow marls below to a glauconite sand above and a "kick" in the gamma-ray log. The hiatus may be less than 0.5 m.y. ( 49.6-49.1 Ma) or as long as 1 m.y. (49.6-48.6 Ma), depending on the assumed sedimentation rate (Figs. 2, 4). Thus, there are at least two major hiatuses associated with the latest early Eocene at all three sites, as noted by Miller et al. (1990) and Christensen et al. (1995) at the ACGS\#4 borehole.
We note at least one, if not two, lowermost middle Eocene (Chron C21r) sequences. All three boreholes contain an upper Chronozone $\mathrm{C} 21 \mathrm{r}$ section dominated by Biofacies $\mathrm{D}$ and $\mathrm{G}$ with a glauconite sand at the base (Fig. 2). The sediments contain up to $50 \%$ carbonate. At ACGS\#4, there may be a unit, not present at Island Beach or Allaire (Fig. 5), that is older than the Island Beach glauconite sand (between 905 and $893 \mathrm{ft}$ [275.8 and $272.2 \mathrm{~m}$ ]; early Chron C21r). This may be a separate sequence at ACGS\#4 (Figs. 2, 5) or it may be the TST of the sequence based on the continued dominance of Siphonina claibornensis in the overlying biofacies (Fig. 5). We cannot choose between these two interpretations at this time. The age of the glauconite unit at ACGS\#4 is $48.5 \mathrm{Ma}$, which is also the most likely age for the base of the sequence at Island Beach. The only occurrence of Discoaster lodoensis at ACGS\#4 is at $890 \mathrm{ft}(271.3 \mathrm{~m})$. We interpret the top of the glauconite associated with the presence of these age-diagnostic fossils as evidence for the MFS.

\section{Sequence E6}

Another unconformity in this interval occurs in sediments correlative to Chronozone C21r ( 48.3 Ma). At Island Beach, a 0.3-m-thick hardground $(846 \mathrm{ft}[257.9 \mathrm{~m}])$ separates two sequences. The unconformity is at $\sim 884 \mathrm{ft}(269.4 \mathrm{~m})$ at ACGS\#4, and the hiatus, which is associated with the boundary between Chronozones C21r and C21n, is from 48.3 to $47.9 \mathrm{Ma}$. The hiatus is associated with a change from Biofacies D, dominated by Siphonina claibornensis, to Biofacies G, dominated by Cibicidoides subspiratus. Sequence E6 is not present at the other boreholes. Calcareous nannoplankton indicate deposition during Biochrons NP14b and NP15a (48.5-46.1 Ma). A layer containing abundant glauconite occurs between 870 and $860 \mathrm{ft}(265.2$ and $262.1 \mathrm{~m}$ ) at ACGS\#4. Both Poore and Bybell (1988) and Aubry (1991) placed an unconformity in the lower part of the Shark River Formation between the lowest occurrences in the core of Discoaster 
sublodoensis at $902 \mathrm{ft}(274.9 \mathrm{~m})$ and Nannotetrina fulgens at $860 \mathrm{ft}$ (262.1 m). Poore and Bybell (1988) suggested that the unconformity was most likely associated with the glauconite layer. This leads to the possibility that two sequences are present between 880 and $844 \mathrm{ft}$ (268.2 and $257.3 \mathrm{~m}$ ) in the core. A more parsimonious explanation is that the glauconite bed represents the condensed section, and the sediments below belong to the TST. The occurrence of Rhabdosphaera inflata at $870 \mathrm{ft}(265.2 \mathrm{~m})$ probably marks deep water and the MFS at $47.5 \mathrm{Ma}$. The sequence between 880 and $844 \mathrm{ft}$ (268.2 and 257.3 $\mathrm{m}$ ) is very fine grained with almost the entire sand fraction composed of foraminiferal tests. It is characterized by Biofacies $\mathrm{G}$ with Factor 9 at the base replaced by Factor 2 at the top.

\section{Sequence E7}

At ACGS\#4, there is an unconformity at $844 \mathrm{ft}(257.3 \mathrm{~m})$. Owens et al. (1988) identified an indurated pyritic layer containing flattened shells at $844 \mathrm{ft}(257.3 \mathrm{~m})$. This is probably the TST immediately above the unconformity. The only occurrence of Blackites gladius is at $843 \mathrm{ft}(256.9 \mathrm{~m})$. The FO of this species is not used as a biostratigraphic marker, but its range is generally confined to Zone NP15c (Figs. 5, 6). This would agree with the absence of Chiasmolithus gigas from the borehole. This also corresponds well with the Chronozone $\mathrm{C} 21 / \mathrm{C} 20$ boundary. The duration of this long hiatus can only be approximately estimated as at least 46.9-44.5 Ma.

A sequence deposited between 44.5 and $\sim 43.4$ Ma occurs at all three boreholes (Fig. 3). The upper portion of this sequence is found at the bottom of the Atlantic City borehole. It comprises roughly 50 $\mathrm{ft}(15.2 \mathrm{~m})$ of section at ACGS\#4, $46 \mathrm{ft}(14.0 \mathrm{~m})$ of section at Island Beach and $20 \mathrm{ft}(6.1 \mathrm{~m})$ of section at Allaire. This sequence is dominated by Biofacies G. At Island Beach the sequence is predominantly clay. The sand fraction contains glauconite at the base, but it quickly becomes $100 \%$ foraminifers. The glauconite layer is more pronounced at ACGS\#4, reaching a maximum at $830 \mathrm{ft}(253.0 \mathrm{~m})$. The amount of quartz relative to glauconite increases upsection. This interpretation for the sediments implies that $B$. gladius (as found by Poore and Bybell, 1988) and $M$. aragonensis (as found by Miller et al., 1990) have premature last occurrences on the coastal plain and that Globigerapsis kugleri has a delayed FO. The increase in glauconite at the base of this sequence, along with the only occurrence of $R$. gladius in the ACGS\#4 and Island Beach boreholes, is evidence that the MFS is near the base of this sequence, which is dated at 44.5 Ma.

\section{Sequence E8}

An unconformity constituting the base of Sequence E8 is found at all four boreholes (800 ft (243.8 m) at Island Beach; $1431 \mathrm{ft}[436.2$ $\mathrm{m}$ ] at Atlantic City; $204 \mathrm{ft}$ [62.2 m] at Allaire; and $792 \mathrm{ft}$ [241.4 m] at ACGS\#4) associated with a hiatus that begins at 43.4 Ma. Morozovella lehneri is found at the top of the underlying Sequence E7 at ACGS\#4 and Atlantic City. The boundary between Zone NP15c and NP16 is difficult to recognize in these sediments. Poore and Bybell (1988) reported $R$. gladius in a single sample, but they concluded that it was more likely ecologically excluded elsewhere in the section and used the last occurrence of Nannotetrina spp. to set the Zone NP15/ NP16 boundary at $802 \mathrm{ft}(244.4 \mathrm{~m})$. This would indicate an age of $43.4 \mathrm{Ma}$ about $10 \mathrm{ft}(3.0 \mathrm{~m})$ below the unconformity. Miller et al. (1990) reported that normally magnetized sediments equivalent to Chron C20n occur in the borehole at the top of this sequence, making the top of the sequence younger than $43.8 \mathrm{Ma}$. The surface separating these two sequences is very sharp, with pale yellow marls below and glauconitic sandy clays above.

Sequence E8 is found from 800 to $780 \mathrm{ft}(243.8-237.7 \mathrm{~m})$ at Island Beach, from 1431 to $1390 \mathrm{ft}(436.2-423.7 \mathrm{~m})$ at Atlantic City, and from 204 to $175 \mathrm{ft}(62.2-53.3 \mathrm{~m})$ at Allaire. The sequence is absent at ACGS\#4. The sediments of this sequence are coarser than those below. At Allaire and Island Beach, they consist of up to 50\% clay. Glauconite dominates in the lower portion of the sequence and fine quartz sand dominates above (Figs. 3, 6). Foraminiferal tests comprise up to $20 \%$ of the sand fraction at Island Beach and at the base of this sequence at Allaire, but only about $5 \%$ of the sediments at the top. Island Beach samples contain 5\% carbonate. At Atlantic City, the sediments are more clay rich and contain a much smaller percentage of glauconite and quartz. Sequence E8 at Allaire was deposited at depths of $50 \pm 15 \mathrm{~m}$, and in the other boreholes at depths of $75 \pm 15 \mathrm{~m}$. Dating these sediments is difficult because of the lack of definitive biostratigraphic indicators in this time period. The sediments are of reversed polarity and were deposited during Biochrons NP16 and P12. All that is certain is that they are either Chronozone C19r or C18r. Therefore, they were either deposited between 42.6 and 41.5 Ma or between 41.25 and 40.5 Ma.

The top of this sequence is poorly defined. The sequence above contains a mixture of biostratigraphic indicators. Middle Eocene (P14 and older) morozovellids and acarininids are found in the same samples as upper Eocene calcareous nannoplankton (Isthmolithus recurvus). This mixture has been found in other boreholes in the New Jersey Coastal Plain (Poore and Bybell, 1988) as well as in DSDP (Miller and Hart, 1987) and ODP boreholes (Snyder et al., 1996). It is likely that its deposition is related to a bolide impact postulated by Poag et al. (1992, 1994). The contact separating Sequence E8 from Sequence E9 is sharp at the Island Beach borehole with a medium to coarse pebbly glauconitic, quartzose sand underlain by a slightly sandy clay (Fig. 6). At Atlantic City, there is no abrupt change in lithology in this interval; there is a glauconitic clay above an pale yellow marl at $1387 \mathrm{ft}(422.8 \mathrm{~m})$ in the core, and by $1380 \mathrm{ft}(420.6 \mathrm{~m})$ glauconite becomes dominant (Fig. 3). This is slightly higher than what would be suggested by the calcareous nannoplankton (Isthmolithus recurvus is at $1390 \mathrm{ft}$ [423.7 m]), but it would seem that the change from original to reworked sediments occurs somewhere in this interval. This sequence is not present in ACGS\#4. Unlike at Island Beach, the sediments above the Shark River Formation at ACGS\#4 are younger than Zone NP16 and are not separated from the biostratigraphically mixed layer by an obvious surface.

The extent of the hiatus associated with the unconformity has not been determined. If the sediments above Sequence E8 are associated with the impact in the Chesapeake Bay impact crater, then they are reworked sediments deposited during Biochron NP19-20 (Poag and Aubry, 1995).

\section{DISCUSSION}

We compare the record of sea-level change from New Jersey to the record of third-order sea-level events developed by Haq et al. (1987) and the global deep-sea $\delta^{18} \mathrm{O}$ record (Kennett and Stott, 1990; Pak and Miller, 1992; Figs. 2, 3). We recalibrated the Haq et al. (1987) record to the Berggren et al. (1995) time scale using the magnetostratigraphy and biostratigraphy provided in the "cycle chart." Whereas the chronology of the New Jersey Eocene sections can be directly tied to the GPTS and has a resolution typically of $0.5 \mathrm{~m}$.y. or better, the Haq et al. (1987) record has a resolution of about 1 m.y. or worse, considering differences in the biochronology presented. Similar to the record of Haq et al. (1987), which showed 14 sequence boundaries, the New Jersey early to middle Eocene record shows primarily punctuated deposition through most of the early to middle Eocene, with nine major sequence boundaries (Figs. 2, 3).

Of the 14 sequence boundaries inferred by Haq et al. (1987) for the lower to middle Eocene, nine are resolvable on the New Jersey Margin, and the remaining five appear to be combined with others. The sequence boundaries at the bases of TA2.2, TA2.3, and TA2.4 cannot be separately resolved, and one or all may correspond to the unconformity dated at $55 \mathrm{Ma}$ (Fig. 2). The TA2.5 (53.5 Ma correlated 
to Berggren et al., 1995) sequence boundary apparently correlates with the unconformity dated as $54.0-53.4 \mathrm{Ma}$, although this is a very small-amplitude $(<20 \mathrm{~m})$ sea-level event according to Haq et al. (1987). The sequence boundaries at the base of TA2.6 (52.8 Ma) and TA2.7 (52.2 Ma) correlate with the unconformity dated as 52.9-52.3 Ma. This sequence is not reflected in the benthic foraminifers from the $>150-\mu \mathrm{m}$-size fraction. The sequence boundaries at the base of TA2.8 (50.7 Ma) and TA2.9 (50.2 Ma) coincide with an unconformity dated as 50.9 to 50.5 or $49.9 \mathrm{Ma}(876 \mathrm{ft}$ [267.0 m] at Island Beach). The TA3.1 (49.7 Ma) sequence boundary apparently coincides with an unconformity dated as $49.6-48.6 \mathrm{Ma}(857 \mathrm{ft}[261.2 \mathrm{~m}]$ at Island Beach). This unconformity was inferred by Haq et al. (1987) to be between Chrons C22r and C22n. We find that this major unconformity, associated with a major facies change, is at the top of Chronozone $\mathrm{C} 22 \mathrm{n}$. There is no correlative sea-level lowering inferred by Haq et al. (1987) associated with the probable unconformity at $862 \mathrm{ft}(262.7$ $\mathrm{m} ; 49.6$ or $49.4 \mathrm{Ma}$ ) at Island Beach, nor is there a correlative sealevel lowering for the possible unconformity at $893 \mathrm{ft}(272.2 \mathrm{~m} ; 48.7$ $\mathrm{Ma})$ at ACGS\#4. The TA3.2 (48.1 Ma) sequence boundary correlates with an unconformity found at ACGS\#4, dated 48.3-47.9 Ma. The TA3.3 (46.2 Ma) sequence boundary is associated with an unconformity at ACGS\#4, dated 46.9-44.5 Ma. The TA3.4 (43.4 Ma) and TA3.5 (41.5 Ma) sequence boundaries coincide with a major unconformity found in the New Jersey Coastal Plain, dating from 43.4 to either 42.5 or $41.2 \mathrm{Ma}$. The final unconformity on the top of this section may not be a result of eustatic change, but may have been caused by the Chesapeake Bay impact.

We are also able to date the MFSs and compare the dates to those of Haq et al. (1987). In these deep neritic sections, each sequence should be dominated by the HST overlying a condensed TST. In the lower and middle Eocene, we see somewhat expanded sections, which sometimes allow us to distinguish and date the MFS. Sequence E1 has an MFS, according to Haq et al. (1987) at 54.3 Ma. At Island Beach we find that the MFS actually occurs at 54.4 or $54.6 \mathrm{Ma}$, depending upon the sedimentation rate chosen. Haq et al. (1987) concluded that the MFS for Sequence E2 should be at 53.2 Ma. This corresponds to the change from Biofacies $\mathrm{H}$ to Biofacies $\mathrm{E}$ and the change in lithology from clay to slightly sandy clay, which we date at 53.1 Ma. Sequence E3 has an inferred MFS of 51.7 Ma. The MFS in Sequence E3 is associated with a change from sediments dominated by clay with a very minor quartz sand fraction to a unit with more fine and very fine sand. This changeover takes place at about 51.8 Ma. Sequence E4 has no obvious MFS. There is no glauconite at the base, implying that the entire unit is a HST. All of the sediments in this sequence are apparently younger than the inferred MFS at $50 \mathrm{Ma}$. The MFS for Sequence TA3.1 is inferred to be at $49 \mathrm{Ma}$. We feel that Haq et al. (1987) misdated this sequence boundary and consequently the MFS. We suggest the glauconite at $893 \mathrm{ft}(272.2 \mathrm{~m})$ in the ACGS\#4 borehole is the MFS, which is here dated as $48.6 \mathrm{Ma}$. Sequence E6 also has a glauconite that is dated at $47.5 \mathrm{Ma}$. This is comparable to the inferred value of $47.4 \mathrm{Ma}$ by Haq et al. (1987). Sequence E7 has a slight increase in glauconite at the base of all three boreholes and contains the only occurrence of $R$. gladius. We conclude that the MFS is coincident with the base of this sequence and that it should be dated at $44.5 \mathrm{Ma}$. This is comparable to the $44.8 \mathrm{Ma}$ of Haq et al. (1987). The MFS for Sequence E8 cannot be dated precisely because of uncertainty in the age of this sequence. It is likely that the MFS lies close to the lower bounding unconformity.

We conclude that the record of Haq et al. (1987) is largely representative of the record of sea-level change for this interval in New Jersey, although we do not resolve some of their smaller events. Although the New Jersey record cannot be used as a "global standard" until verified by studies on other margins, this record provides an excellent chronology of unconformities for the latest Paleocene to early middle Eocene tied to the Berggren et al. (1995) time scale.

The record of sedimentation shows interesting correlations with the $\delta^{18} \mathrm{O}$ record. Covariance of tropical and benthic foraminiferal $\delta^{18} \mathrm{O}$ records has been used by previous authors to infer ice-volume changes (Shackleton and Kennett, 1975; Miller et al. 1991). We evaluate here the relationship, if any, between inferred ice-volume changes and unconformities on the New Jersey Coastal Plain. The oxygen isotope records were taken from the literature and were recalibrated to the Berggren et al. (1995) time scale. No single benthic foraminiferal $\delta^{18} \mathrm{O}$ record covers the entire time interval discussed here, and we have tied together the records from Southern Ocean Site 527 (Shackleton et al., 1984), Pacific Ocean Site 577 (Pak and Miller, 1994), and Southern Ocean Sites 689 and 690 (Kennett and Stott, 1990). The stratigraphy near the P/E boundary at Site 577 is in dispute, and several age models were considered. All benthic foraminiferal $\delta^{18} \mathrm{O}$ records are calibrated and reported to Cibicidoides. The planktonic foraminiferal $\delta^{18} \mathrm{O}$ record from Site 865 (generated on surface-dwelling Morozovella spp., Bralower et al., 1995), was recalibrated to the Berggren et al. (1995) time scale and used for the entire interval (Table 1). Site 865 was a tropical site in the Eocene. Comparison of the benthic and tropical planktonic $\delta^{18} \mathrm{O}$ records shows the following:

1. Global deep-water $\delta^{18} \mathrm{O}$ values decreased through the latest Paleocene to earliest Eocene, indicating deep-water warming, in agreement with other proxies for warm global climates (e.g., Wolfe and Poore, 1982; Sloan, 1994). Lowest $\delta^{18} \mathrm{O}$ values occurred in global deep waters in the early Eocene, a time in which water depths in New Jersey reached their maximum of $\sim 185 \mathrm{~m}$ (Fig. 2; Browning et al., Chapter 16, this volume; Olsson and Wise, 1987b). New Jersey Coastal Plain lower Eocene unconformities do not correlate with increases in the oxygenisotope record. In particular, there are no oxygen isotope increases associated with hiatuses at 55.9-54.7 Ma, 54.0-53.4 $\mathrm{Ma}, 52.9 \mathrm{Ma}$, and 52.3 Ma. Changes in ice volume cannot readily be invoked to explain these unconformities. This leaves open the question of whether these are local phenomena only, or if some other mechanisms caused the unconformities.

2. A large increase in the planktonic $\delta^{18} \mathrm{O}$ record from paleotropical Site 865 (Fig. 2) occurs at $\sim 51 \mathrm{Ma}$, representing a major surface ocean cooling (Bralower et al., 1995). This increase does not appear to correlate with either a poorly resolved benthic foraminiferal $\delta^{18} \mathrm{O}$ increase $(\sim 0.5 \%)$ at Pacific Site 577 or a late early Eocene New Jersey Coastal Plain hiatus (50.9-49.9 Ma). It is doubtful that either $\delta^{18} \mathrm{O}$ increase or the younger unconformity in New Jersey resulted from glacioeustasy.

3. Oxygen-isotopic records near the early/middle Eocene boundary (49.6-48.6 Ma) are too poorly resolved to determine whether unconformities found on the New Jersey Coastal Plain formed as a result of glacioeustasy (Fig. 3). Olsson and Wise (1987b) noted a dramatic shallowing of 50- to 90-m paleowater depth during Biochron CP12a (= NP14a). This shallowing is not preserved in the boreholes studied here. Major lithofacies changes take place on the New Jersey Coastal Plain at this time (Figs. 2, 3), and more work is needed to understand the nature of the unconformities found at that time.

4. Hiatuses in the middle Eocene correlate with benthic foraminiferal oxygen increases, although the middle Eocene record is not as continuous as the lower Eocene (Fig. 3). There are four middle Eocene sequence boundaries in the New Jersey Coastal Plain (Fig. 3). The unconformity at 48 Ma correlates with a poorly constrained increase in planktonic and benthic foraminiferal $\delta^{18} \mathrm{O}$ records of $0.2 \%$ o. This corresponds to a sea-level fall of $18 \mathrm{~m}$ using the Pleistocene sea-level $\delta^{18} \mathrm{O}$ calibration $(0.11 \%$ o/10 m) of Fairbanks and Matthews (1978), or a sealevel fall of $36 \mathrm{~m}$ using the "upper limit" of Miller et al. (1987; $0.055 \%$ o $/ 10 \mathrm{~m}$ ). The hiatus between 46.5 and $44.5 \mathrm{Ma}$ correlates with a large increase in the planktonic oxygen-isotopic record, but there are no high-resolution benthic foraminiferal 
isotopic records for this interval. A benthic foraminiferal $\delta^{18} \mathrm{O}$ record from Site 527 indicates that covariance may be as much as $0.3 \%$ o (27-m sea-level fall with a $55-\mathrm{m}$ sea-level fall upper limit; Fig. 3). The hiatus between 43 and 41 Ma correlates well with an increase in both planktonic and benthic $\delta^{18} \mathrm{O}$ records. Covariance in this case is $0.25 \%$ o (23-m sea level fall with a 45-m sea-level fall upper limit). We note that this unconformity also corresponds to a major drop in water depth of 40 to as much as $100 \mathrm{~m}$, as determined from benthic biofacies changes and a change in lithofacies from carbonate mud dominated to siliciclastic sand dominated (Fig. 3). The youngest hiatus dated here begins at $40 \mathrm{Ma}$ and correlates well with increases in both planktonic and benthic $\delta^{18} \mathrm{O}$ records. Covariance is $0.3 \%$, which corresponds to a sea-level fall of $27 \mathrm{~m}$ using the Fairbanks and Matthews (1978) calibration, or a sea-level fall of $55 \mathrm{~m}$ using the "upper limit." Thus, later middle Eocene unconformities can be readily attributed to glacioeustasy.

The cause of the early Eocene inferred sea-level changes is not clear. Close agreement between the New Jersey record and the Haq et al. (1987) eustatic curve suggests that early Eocene sequence boundaries are globally synchronous. We show that there is little correlation of the early Eocene New Jersey Coastal Plain hiatuses with the $\delta^{18} \mathrm{O}$ record (Figs. 2, 3), so we cannot invoke glacioeustasy in this interval. We would argue that, although it is possible that growth of a small ice sheet occurred several times in the early middle Eocene ( 52-50 Ma), explaining a hiatus on this and other margins (Aubry, 1991), there is little support for early Eocene ice sheets.

It is possible that small glacioeustatic variations have gone undetected. The minimum detectable $\delta^{18} \mathrm{O}$ change is $\sim 0.2 \%$ (or higher with diagenesis and sparse sampling). Thus, a glacioeustatic change of $\sim 18 \mathrm{~m}$ ( $\sim 20 \%$ of present ice volume) is our detection limit using the Pleistocene calibration or $\sim 36 \mathrm{~m}$ using the Miller et al. (1987) upper limit. Our data indicate that sea-level changes were rapid $(<1$ m.y.) and fairly large (>35 m). Our paleodepth estimates show that water-depth changes across these surfaces were on the order of $50 \mathrm{~m}$, which is $\sim 35 \mathrm{~m}$ of eustatic change, correcting for water loading (Steckler and Watts, 1978). Although these water-depth changes do not provide rigorous estimates of relative sea-level changes (i.e., including the effects of loading, compaction, and sediment supply), they are minimal estimates because we do not sample the full range of water-depth variation because of hiatuses and the absence of lowstand deposits. The New Jersey Margin was sediment starved and subject to very slow thermal subsidence $(<10 \mathrm{~m} / \mathrm{m} . \mathrm{y}$.) at this time (e.g., Steckler and Watts, 1978). Although more active tectonics have been proposed for the Atlantic Coastal Plain (e.g., faulting of crustal blocks, Brown et al., 1972), the similarity of the regions throughout New Jersey (Fig. 2) and interregional similarities argue for a more passive regional tectonic history. Thus, we conclude that water-depth changes of the amplitude recorded on the early Eocene New Jersey Margin should be detectable by oxygen-isotope stratigraphy.

Changes in seafloor spreading rates or ridge length are too slow to explain large, rapid (>10 m/m.y.), global sea-level changes (Donovan and Jones, 1979), although associated changes in production and destruction of ocean plateaus potentially can cause relatively large, rapid changes (Larson, 1991; Tarduno et al., 1991). We conclude that mechanisms for sea-level change are still not fully understood.

Late-middle Eocene correlations to the oxygen-isotope curve are more intriguing. Although a few workers (Prentice and Matthews, 1988) have argued for the existence of a continuous ice cap on Antarctica since the beginning of the middle Eocene, the oldest generally accepted evidence of glaciation is early Oligocene. A few studies have extended ice sheets back into the late-middle Eocene. Barron et al. (1991a, 1991b) recovered $300 \mathrm{~m}$ of glaciomarine drift below welldated lowermost Oligocene diamictites at ODP Holes 739C and 742A, Prydz Bay, East Antarctica. A middle Eocene to Oligocene age
Table 1. Datums used to estimate ages of the oxygen-isotope records.

\begin{tabular}{llc}
\hline \multicolumn{1}{c}{ Datum } & $\begin{array}{c}\text { Age } \\
\text { (Ma) }\end{array}$ & $\begin{array}{c}\text { Depth } \\
\text { (m) }\end{array}$ \\
\hline Hole 865B & & \\
LO C. grandis & 37.1 & 19.32 \\
LO C. solitus & 40.4 & 29.4 \\
FO R. umbilicus & 43.7 & 47.31 \\
LO C. gigas & 44.5 & 48.73 \\
FO C. gigas & 46.1 & 67.7 \\
FO N. fulgens & 47.3 & 73.2 \\
FO B. inflatus & 48.5 & 74.0 \\
FO D. sublodoensis & 49.7 & 79.6 \\
LO T. orthostylus & 50.6 & 79.6 \\
FO D. lodoensis & 52.85 & 89.6 \\
LO T. contortus & 53.61 & 91.61 \\
LO M. velascoensis & 54.7 & 100.9 \\
FO D. multiradiatus & 56.2 & 116.21 \\
Hole 527 & & \\
Base C20n & 43.789 & 138.71 \\
LO C. gigas & 44.5 & 138.85 \\
FO C. gigas & 46.1 & 140.77 \\
Top C21n & 46.264 & 143.45 \\
Base C21n & 47.906 & 148.09 \\
Hole 577 & & \\
Top C22n & 49.037 & 67.95 \\
LO T. orthostylus & 50.6 & 72.2 \\
Base C23n & 51.743 & 73.2 \\
Top C24n & 52.364 & 75.45 \\
Base C24n & 53.3 & 79.95 \\
LO T contortus & 53.61 & 80.05 \\
FO T. contortus & 53.93 & 80.7 \\
LO T. digitalis & 54.37 & 80.7 \\
FO T. bramlettei & 55.0 & 82.8 \\
BFE T225n & 55.6 & 82.8 \\
Top C25n & 55.9 & 85.45 \\
Top C26n & 57.55 & 91.47 \\
& & \\
\hline
\end{tabular}

Notes: $\mathrm{FO}=$ first occurrence, $\mathrm{LO}=$ last occurrence, $\mathrm{BFE}=$ benthic foraminiferal extinction

is suggested by the sparse nannoplankton and dinoflagellates. An excellent magnetic polarity record consisting of a mostly normal polarity sequence interrupted by eight short reversals was recovered from Hole 742A. Comparison with the geomagnetic time scale reveals only one interval, Chrons C18-15, with a similar pattern. This is similar in age to the youngest unconformity found here. Birkenmajer (1988) reported glacial tills underlying a tuff bed dated at $49 \mathrm{Ma} \pm 5$ m.y. in the South Shetland Islands, Antarctica, although these tills could be attributed to alpine glaciation. This age is older than the unconformity separating the upper and lower Shark River Formation, and we conclude that there is growing evidence that the initiation of Antarctic ice began as early as $42 \mathrm{Ma}$.

\section{CONCLUSIONS}

We show nine clearly expressed unconformities in the lower to middle Eocene in at least two of our three New Jersey Coastal Plain boreholes and suggest that these are due to regional base-level lowerings. Haq et al. (1987) inferred 14 sea-level events for the same interval, and this suggests that many of the lower Eocene sequences summarized by Haq et al. (1987) are global, although additional sections on other margins are needed to test this. Other studies have recorded coeval unconformities on other margins (e.g., Aubry [1991] detected our early middle Eocene break in northwest Europe and the Irish margin), again supporting global lowerings of sea level at this time.

It is unlikely that early Eocene sequence boundaries are the result of glacioeustasy. Hiatuses from the New Jersey Coastal Plain in this interval do not match increases in the $\delta^{18} \mathrm{O}$ record. Good correlation between the $\delta^{18} \mathrm{O}$ record and the timing of unconformities on the New Jersey Coastal Plain in the late middle Eocene suggests that hiatuses forming at this time may be caused by glacioeustasy. A concomitant increase in the planktonic and benthic $\delta^{18} \mathrm{O}$ records coincides with the 
timing of a hiatus on the New Jersey Coastal Plain between 46.9 and $44.5 \mathrm{Ma}$. Similar increases in the $\delta^{18} \mathrm{O}$ records coincide with the hiatus between 43 and $41 \mathrm{Ma}$ and a corresponding change in sedimentation type from carbonate dominated to siliciclastic dominated. We conclude that these represent evidence of the first Antarctic ice cap and the beginning of the "Icehouse" world.

\section{ACKNOWLEDGMENTS}

We thank the New Jersey Geological Survey for supplying the Allaire core; T. Gibson, M. Katz, T. Moore, R.K. Olsson, R. Poore, J. Self-Trail, and P.J. Sugarman for critically reading this paper; and D. Ostermann for carbonate measurements. The New Jersey Coastal Plain Drilling Project was supported by National Science Foundation Continental Dynamics and Ocean Drilling Programs Grant Number EAR92-18210 and a consortium of oil companies (Amoco, BP, Chevron, Exxon, Marathon, Unocal). This is LDEO contribution number 5695

\section{REFERENCES}

Ali, J.R., and Hailwood, E. A., 1995. Magnetostratigraphy of upper Paleocene through lower middle Eocene strata of northwest Europe. In Berggren, W.A., Kent, D.V., and Hardenbol, J. (Eds.), Geochronology, Time Scales and Global Stratigraphic Correlation. Spec. Publ.-Soc. Econ. Paleontol. Mineral., 54:275-279.

Aubry, M.-P., 1985. Northwestern Europe magnetostratigraphy, biostratigraphy and paleogeography: calcareous nannofossil evidence. Geology, 13:198-202.

1991. Sequence stratigraphy: eustasy or tectonic imprint? J. Geophys. Res., 96:6641-6679.

Bandy, O.L., 1949. Eocene and Oligocene foraminifera from Little Stave Creek, Clarke County, Alabama. Bull. Am. Paleontol., 32:1-211.

Barron, J.A., Baldauf, J.G., Barrera, E., Caulet, J.-P., Huber, B.T., Keating, B.H., Lazarus, D., Sakai, H., Thierstein, H.R., and Wei, W., 1991a. Biochronologic and magnetochronologic synthesis of Leg 119 sediments from the Kerguelen Plateau and Prydz Bay, Antarctica. In Barron, J., Larsen, B., et al., Proc. ODP, Sci. Results, 119: College Station, TX (Ocean Drilling Program), 813-847.

Barron, J.A., Larsen, B., and Baldauf, J.G., 1991b. Evidence for late Eocene to early Oligocene Antarctic glaciation and observations of late Neogene glacial history of Antarctica: results from Leg 119. In Barron, J., Larsen, B., et al., Proc. ODP, Sci. Results, 119: College Station, TX (Ocean Drilling Program), 869-891.

Baum, G.R., and Vail, P.R., 1988. Sequence stratigraphic concepts applied to Paleogene outcrops, Gulf and Atlantic basins. In Wilgus, C.K., Hastings, B.S., Kendall, C.G.St.C., Posamentier, H.W., Ross, C.A., and Van Wagoner, J.C. (Eds.), Sea-level Changes: An Integrated Approach. Spec. Publ[0151]Soc. Econ. Paleontol. Mineral., 42:309-327.

Berggren, W.A., and Aubry, M.-P., 1996. A late Paleocene-early Eocene NW European and North Sea magnetobiochronological correlation network. In Knox, R.W. O'B., Corfield, R.M., and Dunay, R.E. (Eds.), Correlation of the Early Paleogene in Northwest Europe. Geol. Soc. Spec. Publ. London, 101:309-352.

Berggren, W.A., Kent, D.V., Swisher, C.C., and Aubry, M.-P., 1995. A revised Cenozoic geochronology and chronostratigraphy. In Berggren, W.A., Kent, D.V., and Hardenbol, J. (Eds.), Geochronology, Time Scales and Global Stratigraphic Correlations: A Unified Temporal Framework for an Historical Geology. Spec. Vol.-Soc. Econ. Paleontol. Mineral., 54:129-212.

Birkenmajer, K., 1988. Tertiary glacial and interglacial deposits, South Shetland Islands, Antarctica: geochronology versus biostratigraphy (a progress report). Bull. Pol. Acad. Sci. Earth Sci., 36:133-144.

Bolli, H.M., 1957a. The genera Globigerina and Globorotalia in the Paleocene-lower Eocene Lizard Springs Formation of Trinidad, B.W.I. In Loeblich, A.R., Jr. (Ed.), Studies in Foraminifera. Bull.-U.S. Nat. Mus., 215:61-81.

Bolli, H.M., 1957b. Planktonic foraminifera from the Eocene Navet and San Fernando formations of Trinidad, B.W.I. In Loeblich, A.R., Jr. (Ed.), Studies in Foraminifera. Bull.-U.S. Nat. Mus., 215:155-172.
Bralower, T.J., Zachos, J.C., Thomas, E., Parrow, M., Paull, C.K., Kelly, D.C., Premoli Silva, I., Sliter, W.V., and Lohmann, K.C., 1995. Late Paleocene to Eocene paleoceanography of the equatorial Pacific Ocean: stable isotopes recorded at Ocean Drilling Program Site 865, Allison Guyot. Paleoceanography, 10:841-865.

Brown, P.M., Miller, J.A., and Swain, F.M., 1972. Structural and stratigraphic framework, and spatial distribution of permeability of the Atlantic Coastal Plain, North Carolina to New York. Geol. Surv. Prof. Pap. U.S., 796.

Bybell, L.M., and Self-Trail, J.M., 1995. Evolutionary, biostratigraphic, and taxonomic study of calcareous nannofossils from a continuous Paleocene/Eocene boundary section in New Jersey. Geol. Surv. Prof. Pap. U.S., 1554 .

Charletta, A.C., 1980. Eocene benthic foraminiferal paleoecology and paleobathymetry of the New Jersey continental margin [Ph.D. dissert.]. Rutgers University, New Brunswick, NJ.

Christensen, B.A., Miller, K.G., and Olsson, R.K., 1995. Eocene-Oligocene benthic foraminiferal biofacies and depositional sequence at the ACGS\#4 borehole, New Jersey Coastal Plain. Palaios, 10:103-132.

Clark, W.B., 1894. Cretaceous and Tertiary geology; report of progress. Ann. Rep. State Geol., New Jersey Geol. Surv.

Conrad, T.A., 1865. Observations on the Eocene lignite formation of the United States. Proc. Acad. Sci. Philadelphia, 17:70-73.

Cook, G.H., 1868. The geology of New Jersey. Geol. Surv. New Jersey, 263242.

Donovan, D.T., and Jones, E.J.W., 1979. Causes of world-wide changes in sea level. J. Geol. Soc. London, 136:187-192.

Enright, R., 1969a. The stratigraphy and clay mineralogy of Eocene sediments of the northern New Jersey coastal plain. In Subitsky, S. (Ed.), Geology of Selected Areas in New Jersey and Eastern Pennsylvania and Guidebook of Excursions: New Brunswick, NJ (Rutgers University Press), 14-20.

Enright, R., 1969b. The stratigraphy, micropaleontology, and paleoenvironmental analysis of the Eocene sediments of the New Jersey coastal plain [Ph.D. dissert.]. Rutgers University, New Brunswick, NJ.

Fairbanks, R.G., and Matthews, R.K., 1978. The marine oxygen isotopic record in Pleistocene coral, Barbados, West Indies. Quat. Res., 10:181196.

Gibson, T.G., and Buzas, M.A., 1973. Species diversity: pattern in Modern and Miocene Foraminifera of the eastern margin of North America. Geol. Soc. Am. Bull., 84:217-238.

Gibson, T.G., Bybell, L.M., and Owens, J.P., 1993. Latest Paleocene lithologic and biotic events in neritic deposits of southwestern New Jersey. Paleoceanography, 8:495-514.

Haq, B.U., Hardenbol, J., and Vail, P.R., 1987. Chronology of fluctuating sea levels since the Triassic. Science, 235:1156-1167.

Hazel, J.E., Edwards, L.E., and Bybell, L.M., 1984. Significant unconformities and the hiatuses represented by them in the Paleogene of the Atlantic and Gulf Coastal Province. In Schlee, J. (Ed.), Interregional Unconformities: AAPG Mem., 36:59-66.

Imbrie, J., Barron, E.J., Berger, W.H., Bornhold, B.D., Cita-Sironi, M.B., Diester-Haass, L., Elderfield, H., Fischer, A.G., Lancelot, Y., Prell, W.L., Toggweiler, J.R., and Van Hinte, J.E., 1987. Scientific goals of an Ocean Drilling Program designed to investigate changes in the global environment. In Rep. 2nd Conf. Scientific Ocean Drilling (COSOD II), JOIDES, $15-46$.

Jones, G.D., 1983. Foraminiferal biostratigraphy and depositional history of the Middle Eocene rocks of the coastal plain of North Carolina. North Carolina Geol. Surv. Spec. Publ., 8:1-80.

Kennett, J.P., and Stott, L.D., 1990. Proteus and Proto-oceanus: ancestral Paleogene oceans as revealed from Antarctic stable isotopic results: ODP Leg 113. In Barker, P.F., Kennett, J.P., et al., Proc. ODP, Sci. Results, 113: College Station, TX (Ocean Drilling Program), 865-880.

Larson, R.L., 1991. The latest pulse of Earth: evidence for a mid-Cretaceous superplume. Geology, 19:547-550.

Loutit, T.S., Hardenbol, J., Vail, P.R. and Baum, G.R., 1988. Condensed sections: the key to age determination and correlation of continental margin sequences. In Wilgus, C.K., Hastings, B.S., Ross, C.A., Posamentier, H.W., Van Wagoner, J., and Kendall, C.G.St.C. (Eds.), Sea-Level Changes: An Integrated Approach. Spec. Publ.—Soc. Econ. Paleontol. Mineral., 42:183-213.

Mancini, E.A., and Tew, B.H., 1991. Relationship of Paleocene stage and planktonic foraminiferal zone boundaries to lithostratigraphic and allo- 
stratigraphic contacts in the eastern Gulf coastal Plain. J. Foraminiferal Res., 21:48-66.

Miller, K.G., 1992. Middle Eocene to Oligocene stable isotopes, climate, and deep-water history: the Terminal Eocene Event? In Prothero, D., and Berggren, W.A. (Eds.), Eocene-Oligocene Climatic and Biotic Evolution: Princeton, NJ (Princeton Univ. Press), 160-177.

Miller, K.G., Browning, J.V., Liu, C., Sugarman, P., Kent, D.V., Van Fossen, M., Queen, D., Goss, M., Gwynn, D., Mullikin, L., Feigenson, M.D., Aubry, M.-P., and Burckle, L.D., 1994a. Atlantic City site report. In Miller, K.G., et al., Proc. ODP, Init. Repts., 150X: College Station, TX (Ocean Drilling Program), 35-55.

Miller, K.G., Fairbanks, R.G., and Mountain, G.S., 1987. Tertiary oxygen isotope synthesis, sea-level history, and continental margin erosion. Paleoceanography, 2:1-19.

Miller, K.G., and Hart, M.B., 1987. Cenozoic planktonic foraminifers and hiatuses on the New Jersey Slope and Rise: Deep Sea Drilling Project Leg 95, northwest Atlantic. In Poag, C.W., Watts, A.B., et al., Init. Repts. DSDP, 95: Washington (U.S. Govt. Printing Office), 253-265.

Miller, K.G., Kent, D.V., Brower, A.N., Bybell, L.M., Feigenson, M.D., Olsson, R.K., and Poore, R.Z., 1990. Eocene-Oligocene sea-level changes on the New Jersey coastal plain linked to the deep-sea record. Geol. Soc. Am. Bull., 102:331-339.

Miller, K.G., Liu, C., and Feigenson, M.D., 1996. Oligocene to middle Miocene Sr-isotopic stratigraphy of the New Jersey continental slope. In Mountain, G.S., Miller, K.G., Blum, P., Poag, C.W., and Twichell, D.C. (Eds.), Proc. ODP, Sci. Results, 150: College Station, TX (Ocean Drilling Program), 97-114.

Miller, K.G., Sugarman, P., Van Fossen, M., Liu, C., Browning, J.V., Queen, D., Aubry, M.-P., Burckle, L.D., Goss, M., and Bukry, D., 1994b. Island Beach site report. In Miller, K.G., et al., Proc. ODP, Init. Repts., 150X: College Station, TX (Ocean Drilling Program), 5-33.

Miller, K.G., Wright, J.D., and Fairbanks, R.G., 1991. Unlocking the Ice House: Oligocene-Miocene oxygen isotopes, eustasy, and margin erosion. J. Geophys. Res., 96:6829-6848.

Olsson, R.K., and Wise, S.W., 1987a. Upper Maestrichtian to middle Eocene stratigraphy of the New Jersey slope and coastal plain. In van Hinte, J.E., Wise, S.W., Jr., et al., Init. Repts. DSDP, 93 (Pt. 2): Washington (U.S. Govt. Printing Office), 1343-1365.

, 1987b. Upper Paleocene to middle Eocene depositional sequences and hiatuses in the New Jersey Atlantic Margin. In Ross, C., and Haman, D. (Eds.), Timing and Depositional History of Eustatic Sequences: Constraints on Seismic Stratigraphy. Spec. Publ. Cushman Found. Foraminiferal Res., 24:99-112.

Ostermann, D.R., Karbott, D., and Curry, W.B., 1990. Automated system to measure the carbonate concentration of sediments. WHOI Tech. Rep., $90-103$.

Owens, J.P., Bybell, L.M., Paulachok, G., Ager, T.A., Gonzalez, V.M., and Sugarman, P.J., 1988. Stratigraphy of the Tertiary sediments in a 945foot-deep corehole near May's Landing in the southeastern New Jersey Coastal Plain. Geol. Surv. Prof. Pap. U.S., 1484.

Pak, D.K., 1995. Paleocene and Eocene deep-water circulation, climate and sea level [Ph.D. dissert.]. Columbia University, Palisades, NY.

Pak, D.K., and Miller, K.G., 1992. Paleocene to Eocene benthic foraminiferal isotopes and assemblages: implications for deepwater circulation. Paleoceanography, 7:405-422.

1994. Isotopic, magneto-, and biostratigraphy of the upper Paleocene to lower Eocene Manasquan Formation, Island Beach, New Jersey. Eos, 75:57.

1995. Isotopic and faunal record of Paleogene deep-water transitions in the North Pacific. In Rea, D.K., Basov, I.A., Scholl, D.W., and Allan, J.F. (Eds.), Proc. ODP, Sci. Results, 145: College Station, TX (Ocean Drilling Program), 265-281.

Pitman, W.C., III, and Golovchenko, X., 1983. The effect of sea level change on the shelf edge and slope of passive margins. Spec. Publ.-Soc. Econ. Paleontol. Mineral., 33:41-58.

Plint, A.G, 1988. Global eustasy and the Eocene sequences in the Hampshire Basin, England. Basin Res., 1:11-22.

Poag, C.W., and Aubry, M.-P., 1995. Upper Eocene impactites of the U.S. East Coast: depositional origins, biostratigraphic framework, and correlation. Palaios, 10:16-43.
Poag, C.W., Powars, D.S., Poppe, L.J., and Mixon, R.B., 1994. Meteroid mayhem in Ole Virginny: source of the North American tektite strewn field. Geology, 22:691-694.

Poag, C.W., Powars, D.S., Poppe, L.J., Mixon, R.B., Edwards, L.E., Folger, D.W., and Bruce, S., 1992. Deep Sea Drilling Project Site 612 bolide event: new evidence of a late Eocene impact-wave deposit and a possible impact site, U.S. east coast. Geology, 20:771-774.

Poore, R.Z., and Bybell, L.M., 1988. Eocene to Miocene biostratigraphy of New Jersey core ACGS \#4: implications for regional stratigraphy. Geol. Surv. Prof. Pap. U.S., 1829.

Posamentier, H.W., Jervey, M.T., and Vail, P.R., 1988. Eustatic controls on clastic deposition, I. Conceptual framework. In Wilgus, C.K., Hastings, B.S., Ross, C.A., Posamentier, H.W., Van Wagoner, J., and Kendall, C.G.St.C. (Eds.), Sea-Level Changes: An Integrated Approach. Spec. Publ.-Soc. Econ. Paleontol. Mineral., 42:109-124.

Powell, A.J., 1992. Making the most of microfossils. Geoscientist, 2:12-16.

Prentice, M.L., and Matthews, R.K., 1988. Cenozoic ice-volume history: development of a composite oxygen isotope record. Geology, 16:963966.

Shackleton, N.J., Hall, M.A., and Boersma, A., 1984. Oxygen and carbon isotope data from Leg 74 foraminifers. In Moore, T.C., Jr., Rabinowitz, P.D., et al., Init. Repts. DSDP, 74: Washington (U.S. Govt. Printing Office), 599-612.

Shackleton, N.J., and Kennett, J.P., 1975. Paleotemperature history of the Cenozoic and the initiation of Antarctic glaciation: oxygen and carbon isotope analyses in DSDP Sites 277, 279, and 281. In Kennett, J.P., Houtz, R.E., et al., Init. Repts. DSDP, 29: Washington (U.S. Govt. Printing Office), 743-755.

Sloan, L.C., 1994. Equable climates during the early Eocene: significance of regional paleogeography for North American climate. Geology, 22:881884.

Snyder, S.W., Miller, K.G., and Saperson, E., 1996. Paleogene and Neogene planktonic foraminiferal biostratigraphy of the New Jersey continental slope: Sites 902, 903, and 904. In Mountain, GS., Miller, KG., Blum, P., Poag, CW., and Twichell, DC. (Eds.), Proc. ODP, Sci. Results, 150: College Station, TX (Ocean Drilling Program), 3-15.

Steckler, M.S., Seranne, M., and Lavier, L., 1995. From carbonate ramps to clastic progradation: morphology and stratigraphy of continental margins during Tertiary global change. Eos, 76:S118.

Steckler, M.S., and Watts, A.B., 1978. Subsidence of Atlantic-type continental margin off New York. Earth Planet. Sci. Lett., 41:1-13.

Sugarman, P.J., Miller, K.G., Owens, J.P., and Feigenson, M.D., 1993. Strontium-isotope and sequence stratigraphy of the Miocene Kirkwood Formation, southern New Jersey. Geol. Soc. Am. Bull., 105:423-436.

Sugarman, P.J., Owens, J.P., and Bybell, L.M., 1991. Geologic map of the Adelphia and Farmingdale Quadrangles, Monmouth and Ocean Counties, New Jersey. NJ Geol. Surv., Geol. Map Series, 91-1.

Tarduno, J.A., Sliter, W.V., Kroenke, L., Leckie, M., Mayer, H., Mahoney, J.J., Musgrave, R., Storey, M., and Winterer, E.L., 1991. Rapid formation of Ontong Java Plateau by Aptian mantle plume volcanism. Science, 254:399-403.

Tucholke, B.E., and Mountain, G.S., 1979. Seismic stratigraphy, lithostratigraphy, and paleosedimentation patterns in the North American Basin. In Talwani, M., Hay, W., and Ryan, W.B.F. (Eds.), Deep Drilling Results in the Atlantic Ocean: Continental Margins and Paleoenvironment. Am. Geophys. Union, Maurice Ewing Ser., 3:58-86.

Ulrich, B.C., 1976. The Eocene foraminiferal biostratigraphy of the Atlantic Coastal Plain of New Jersey [M.S. thesis]. Rutgers University, New Brunswick, NJ.

van Morkhoven, F.P.C.M., Berggren, W.A., and Edwards, A.S., 1986. Cenozoic cosmopolitan deep-water benthic foraminifera. Bull. Cent. Rech. Explor-Prod. Elf-Aquitaine, Mem. 11.

Wolfe, J.A., and Poore, R.Z., 1982. Tertiary marine and nonmarine climatic trends. In Berger, W.H., and Crowell, J.C. (Eds.), Climate In Earth History. Nat. Acad. Sci. U.S., 154-158.

Date of initial receipt: 1 February 1996

Date of acceptance: 7 October 1996

Ms 150XSR-315 